\title{
(Re)Commoning Food and Food Systems. The Contribution of Social Innovation from Solidarity Economy
}

\author{
Adanella Rossi ${ }^{1, *}$, Mario Coscarello ${ }^{2}$ and Davide Biolghini ${ }^{3}$ \\ 1 Department of Agriculture, Food and Environment, University of Pisa, 56124 Pisa, Italy \\ 2 Department of Political and Social Sciences, University of Calabria, 87036 Rende, Italy; \\ mario.coscarello@unical.it \\ 3 Forum Cooperazione e Tecnologia, 20146 Milano, Italy; biolghini@forumct.it \\ * Correspondence: adanella.rossi@unipi.it
}

check for

updates

Citation: Rossi, A.; Coscarello, M.; Biolghini, D. (Re)Commoning Food and Food Systems. The Contribution of Social Innovation from Solidarity Economy. Agriculture 2021, 11, 548. https://doi.org/10.3390/ agriculture 11060548

Academic Editors: Giaime Berti,

Francesca Forno, Marzia Mauriello and Sanzidur Rahman

Received: 27 April 2021

Accepted: 8 June 2021

Published: 15 June 2021

Publisher's Note: MDPI stays neutral with regard to jurisdictional claims in published maps and institutional affiliations.

Copyright: (C) 2021 by the authors. Licensee MDPI, Basel, Switzerland. This article is an open access article distributed under the terms and conditions of the Creative Commons Attribution (CC BY) license (https:/ / creativecommons.org/licenses/by/ $4.0 /)$.

\begin{abstract}
The need for a transition to sustainable food systems is widely recognised. Over the last three decades, movements have been demanding and proposing a radical transformation, foregrounding the social values of food. Experiences inspired by solidarity economy have given rise to highly innovative pathways, grounded on the redefinition of the food-related values and practices and the reconstruction of local, community-based food systems by referring to social and ecological sustainability. One can usefully draw from these experiences for identifying challenges, opportunities and benefits and for analysing the most effective modes of action leading to the creation of alternatives. Capturing and supporting this innovation is particularly important when looking at the opportunities offered by local food policies. This significantly involves the meanings, goals and forms that food governance takes on. The paper aims at investigating these aspects, reading the initiatives inspired by SE principles as an example of social innovation. Their engagement in re-signifying food in terms of "commons" and in "commoning" food systems constitutes a complementary key of analysis. Focusing on the Italian context, the paper draws on many years of qualitative research and direct involvement in these initiatives. The analysis provides useful insights about the potential for change existing in society and invites us to develop reflexivity on how local food policies capture the opportunity for a re-politicisation of food-related issues.
\end{abstract}

Keywords: solidarity economy; social innovation; grassroots innovation; food governance; food as commons; food re-commonification; communing; re-politicisation of food

\section{Introduction}

There is now a wide acknowledgement of the negative impacts of the dominant agrifood system in ecological, social, cultural and economic terms [1-11]. In a consolidated framework of environmental crisis as well as one of increasing social and economic vulnerabilities, the urgency of a transition to alternative, more sustainable models is particularly evident [12-14]. The COVID pandemic has further highlighted the fragility, ecological risks and deep inequalities and injustices associated with the dominant agri-food system $[11,15,16]$, pointing out the need for a systemic approach to food-related issues and confirming the urgency of a change in trajectory.

During the last three decades, food movements all over the globe have denounced the "failures" of the globalized world economy of food, demanding and proposing changes in how food and agriculture are conceived and managed. The debate and the large body of scientific literature on "alternative food networks" (see, among many others, [17-22]) have explored various innovation aspects of these pathways and contributed to evaluating their "alterity". A growing interest in their capacity to develop emancipatory alternatives and their transformative potential (see, within a still open list, [17,22-34]) has also emerged.

At the intersection between food movements and broader social movements contesting the neoliberal model lie initiatives inspired by the principles of "solidarity economy" 
(from here on, SE) [35-39]. Their radical criticism of the dominant agri-food model has contributed to uncovering the negative implications of industrial food production and consumption and has redefined and reconstructed food practices based on mutualism, social justice and ecological sustainability. In its maturity, the movement is engaged in refining alternative instruments and models, but at the same time, in seeking new and more effective ways to contribute to transformation, by also entering spaces of food democracy within governance arenas [40].

In the wide panorama of grassroots innovations around food, this paper focuses on these experiences, considering them particularly significant community-based and politically oriented pathways of rethinking food meanings and practices. Indeed, these initiatives are examples of social spaces that have self-(re)organised around different ways of conceiving food and food-related practices and engaged in building true alternatives aimed at enacting a different model. The collective effort is supported by a comprehensive understanding of the interconnected failures of the dominant food system and by a shared willingness to find ways to overcome such failures. These transformative features look significant in a perspective of transition to a post-neoliberal eco-economy [41]. The conscious pursuit of alternatives is even more meaningful considering the capacity of appropriation and co-optation of any forms of innovation by corporate power in the dominant food system $[24,25,42-44]$ and, thus, the risk of weakening any transformative potential.

The initiatives described here are also extremely relevant for the definition of new food governance models, considering the collective reflexive attitude and the politically oriented agency they express, in the specific form that some scholars have defined as the emerging "politics of collectivity" [45]. Through their action, the initiatives suggest the need for innovative configurations and new aims, challenging the democratic institutions around food-related decision making. In the context of widespread interest in food system re-localisation and activation of new food policies at the local level, aimed at overcoming the deficiencies of higher governance levels in addressing vulnerabilities and shortcomings in term of sustainability of the current food system [46-53], grasping and supporting this innovation seems crucial.

Hence, the following questions guide this paper's analysis: What are the elements of innovation that food-related initiatives inspired by SE principles bring? What are the challenges posed to local food policies from a sustainability transition perspective? What are the governance implications of capturing this innovation potential? To explore these aspects, we look at the Italian context, where these initiatives have started developing since the mid-1990s, albeit with regional differences, varying in terms of scale of action and transformative potential, also as an effect of their evolution over time [54-58]. In recent years and in specific urban contexts, these initiatives have intersected with pathways of local food policy making, with different outcomes in terms of active participation and engagement [59-61].

The paper is organised as follows. Section 2 illustrates the rise in awareness and criticism about the failures of the dominant agri-food system and the mobilisation by civil society to search for alternatives. This section also introduces the experience of SE movement, focusing on the features it takes on in the Italian context and its initiatives around food. Section 3 illustrates the methodological aspects and the conceptual-analytical framework adopted. In Section 4, the evolution of the Italian food-related SE initiatives is described, focusing on the increase in actors' engagement and mutual commitment and the advancement in the pursued goals. Section 5 explores the initiative innovative and transformative potential through the lens of "social innovation", highlighting the societal needs from which they stem, the role of social interactions in the search of new solutions, and how these solutions are aimed at social utility. Section 6 analyses the elements relevant for the development of innovative local food policies aimed at promoting processes of ecological, cultural, social and economic transformation of local food systems. Section 7 focuses on governance issues, looking at the factors most critical for capturing the 
innovation potential expressed by these segments of society. Finally, Section 8 summarises the main findings while opening up further lines of research.

\section{The Need to Reshape Food Systems}

\subsection{Awareness Raising about the Failures of the Dominant Agri-Food System}

It is now widely recognised that the development of the agri-food system, through the profound transformations affecting production, processing and distribution, has generated negative impacts in environmental, economic and social terms. The globalized and industrial agri-food model has changed the relationship with environmental resources, impacting soil fertility, climate, water, agri-biodiversity and ecosystems (see, among many others, [3,5-8]), as well as having had negative effects on consumers' health, for instance by increasing diet-related diseases $[1,2,4,9-11,62,63]$. Furthermore, the dominant model has shown a marked overall inefficiency in the use of resources, resulting in a great deal of unsustainable waste [64,65]. Moreover, over-exploitation of farm labourers has been increasingly foregrounded as a structural component of specialised agri-industrial systems. Numerous studies have demonstrated the growing corporate control within the agri-food system and its economic and social effects [11,66-70]. More specifically, many scholars have highlighted the impact of agriculture intensification, industrialisation and specialisation in terms of economic unsustainability and loss of knowledge and control by farmers $[11,71-76]$. On the consumption side, many studies have investigated the transformations induced in consumers' knowledge and skills about food and in the related diet patterns $[21,70,77,78]$. Sage speaks of "a massification and de-culturalisation of food and eating practices" [34] (p. 5). Looking at the dynamics involving rural and urban contexts under the forces of industrialisation and commodification of food systems, some scholars have unveiled citizens' lack of experience and knowledge of human/nature relations, pointing out the deep cultural and social transformation occurred [79].

The international scientific community and numerous institutions have paid increasing attention and expressed strong concern about these issues, recognizing the need for an urgent transition to environmental and socially sustainable food systems $[9,11,12,14,72,80-83]$. The awareness of the need to create an adequate, innovative framework for agricultural and food policies, capable of adopting a systemic perspective, has spread [13,14,84-87].

Alongside this effort, an interest has grown among scholars and public institutions in redesigning the complex relationship with food and its management on a local scale. This has progressively appeared as a possible complementary or more efficient way to address the abovementioned crises, to adopt integrated approaches as well as to enact the processes of decentralisation and re-democratisation of food-related decision making $[11,46-51,53,88-90]$. The local scale, where the place-based dimension may coincide with sub-national contexts or more specific "city/region" food systems [52], has become the key space where one can develop new food governance forms (in terms of composition and mechanisms), allowing civil society, local governments and economic actors to co-operate in food policy making through rebalanced power relationships. By integrating all resources and reordering priorities, these new governance configurations can lead to effective food policies suited to communities' needs [91-93]. The establishment of food policy councils and the development of integrated food strategies are the main mechanisms to that end. They can be instrumental to a widespread and coordinated development of place-based, resilient food systems, which are seen as conducive to broader food system transformation [94]. Reconfiguring food systems in sustainable terms, integrating all the dimensions (environmental, economic, social) and governing areas involved $[95,96]$ and doing this in truly inclusive and democratic ways by designing new local food governance systems as spaces of equal participation and deliberation [59,92,97-99] are the challenges these processes face. 


\subsection{The Development of Criticism and the Search for Alternatives within Civil Society and the SE Movement}

Even before this general awareness arose, the search for alternatives to the dominant agri-food system has been in place since the 1980s. This has resulted in various experiences of re-connection between production and consumption, based on new ways of relating around food and its values, including new frames, social spaces and organisational models to conceive and manage material, symbolic and economic exchanges [17-22,74,100-102]. Within a wide range of pathways, distinguished for their degree of "alterity" and more or less comprehensive approach in questioning the mainstream system $[28,31,44,103]$, this movement included initiatives driven by a social and economic perspective radically different from the one which informs the globalised, agri-industrial model [104], considered as responsible for many negative externalities and the "commodification" of food $[105,106]$. This perspective built on the recognition of: the multiple values of food-nutritional, but also ecological, cultural, social, ethical; the intrinsic linkage between natural and social components of food systems; the importance of social and community relationships mobilised around food production and consumption and, hence, the value of place-based production systems; the dignity of farm work and the role of small-scale farming; the value of food culture and knowledge.

These alternative pathways around food have been interpreted as a whole as processes of "re-socialization" and "re-spatialisation" ("re-localisation") of food systems and practices [102,107-111]. The development of a new "food citizenship", expressing the sense of civic engagement around food issues, has been considered an accompanying element of these processes [112-114]. Among them, the most radical pathways have been also seen as manifestations of an increasing importance attached to the "food justice" dimension [115] and of a growing desire for self-determination and sovereignty on food. These perspectives were first shared among farmers' movements, underpinning a form of resistance, and since, have involved into other civil society segments, both globally and locally [74,116-119]. Within these pathways, both the ideas of food citizenship and of food sovereignty have developed through collective processes of awareness and agency building, which have made them more politically oriented perspectives [22,31,120-122].

Much of the above-mentioned radical grassroots innovation was born and developed within the SE movement. This is a broad worldwide movement, which aims at defining and actualising an alternative to the dominant economic system inspired by criteria of social equity and justice, cooperation and environmental sustainability $[35,36]$. Active since the 1980s in several countries around the world, in the late 1990s the movement organised itself into an international network-The Intercontinental Network for the Promotion of Social Solidarity Economy (RIPESS); later on, in 2011, a European network was also set up (RIPESS Europe). In 2013, the movement was also recognised by the United Nations Organisation; an UN Inter-agency Task Force on Social Solidarity Economy (TFSSE) was created, which, in 2014, published a position paper proposing to recognise and enhance the role of the social and solidarity economy in achieving the Sustainable Development Goals [123]. Although the term "social solidarity economy" has been adopted by the movement at an international level, a difference is, however, recognised within it: "While the social economy often sought to supplement or complement the existing social order, solidarity economy advocated a more transformative approach to economic activism." [36] (p. 2), [38].

The SE movement focuses on the issues of redistributive justice and alternatives to the neoliberal capitalist model, financialisation and the debt-based monetary system; it also builds on the issues of participatory-deliberative democracy and emancipatory processes based on active citizenship and social activism, integrating economic, social, cultural and environmental objectives and the political dimension [37-39]. The social re-embeddedness and democratisation of the economy are considered central steps in pursuing the sustainable development of territories and communities. In this sense, SE aims to contribute to creating a new discourse on transition, re-founding the concept of 
sustainable development through a perspective that prioritizes social utility and, for its identification and management, collective intelligence and deliberative democracy in local public arenas [37].

Compared to the myriad of initiatives attributed to "alternative food networks" [21], the initiatives inspired by SE have developed within a dimension of trans-local movement [124] and as place-based manifestations of a shared political project of societal change [125]. As such, they are an expression of an intentional, collectively driven effort to redesign food practices, through a radical, paradigmatic shift from the "corporate food regime" [67], its logics and rules. Building alternative visions and practices around food (as well as other needs) is experienced as a way to carry out broader transformative processes. This can be pursued at different scales, from the micro-scale of place-based/communitydriven initiatives, to the meso-scale of assemblages and forms of convergence among similar initiatives or interactions with public institutions (e.g., at the local or national scale), to the wider scale of international movements, playing a role in higher cultural-political arenas.

Alternative initiatives around food that develop within this movement indeed benefit from this shared political project dimension and, before that, from the collective process of empowerment and creation of operational conditions that support individual action. These transformative features are meaningful, as they represent an advancement with respect to the traditional market-based forms of democracy (and power) attributed to citizens as consumers, based on their presumed sovereignty. Doing so, they counter one of the most effective ways by which the system keeps control on food practices, grounded on the capacity to co-opt any new societal aspiration and practice. In fact, the risk is often pointed out that even alternative practices may contribute to the reproduction and consolidation of the neoliberal model $[24,25,42-44]$.

\section{The Italian SE Movement and the Pathways around Food}

In Italy, the SE movement developed since the 1980s around diverse innovative grassroots experiences. These included initiatives aimed at ethically rebuilding finance and credit (e.g., forms of micro-credit based on mutualistic approaches, often locally based), trade relations between the North and South of the world (fair trade), lifestyle and modes of consumption (models inspired by sobriety and sustainability) and, more specifically, practices around food. Following the networking experiences of other countries and regions (France, Spain, South America), the Italian movement took form as an informal network in 2003 (Italian Network of SE) [54]. It grew involving locally based networks and national-sized organisations, all sharing the criticism to the neoliberal capitalist system and the commitment to enact alternative socio-economic models centred on the needs of living beings-as opposed to goals of growth and profits. The choice of a reticular structure was intended to recognise the central role of the processes that developed at a territorial scale, aimed at rebuilding community infrastructures and, within them, new forms of economic and not-economic exchanges; at the same time, it also met the need for sharing and coordination at national level. In the early 2020s, in order to increase its visibility and operational effectiveness, the national network took on a legal status of association.

Among the food-related initiatives that have been developed under the umbrella of SE over time, the following can be mentioned:

- The Solidarity-based Purchase Groups (GAS, from the acronym in Italian)—selforganised groups of consumers managing direct relationships with (mainly) smallscale producers, based on ethical principles of fairness, mutuality and shared commitment to sustainability of food/non-food practices; most of them were set up during the 2000s [55-57,126-134];

- $\quad$ Farmers' markets autonomously organized by producers and inspired by food sovereignty principles [135] (these markets differ from those promoted and run by other organisations for their members, such as "Mercati della Terra" of Slow Food or "Mercati di Campagna Amica" of Coldiretti-the main national farmers' union); 
- Food cooperatives and other forms of "small-scale organized distribution"—aimed at collectively managing the distribution of considerable volumes of products (although small, compared to conventional channels), also coming from other regions, often through consumer involvement as volunteers [31,55,128];

- Community-supported agriculture (CSA) — based on a long-term commitment of groups of consumers to support the activities of one or more farmers, pre-financing and taking on the economic risk; some pioneering initiatives have been in place since 2011, but it is mainly in recent years that this model has started taking off [55,136-138]; - Other more specific initiatives based on agreements ("pacts") between groups of consumers (mainly GAS or their networks) and producers, envisioning a closer mutual commitment around the provisioning of certain food products, based on fair prices collectively set by taking into account all production costs and pre-financing [31,55,128,139];

- A myriad of other initiatives, of a more localised or contingent nature, united by the reference to the aforementioned principles of mutualism and social and environmental justice $[140,141]$.

We will return to these initiatives and their evolution later in the article.

In line with the international evolution of SE movements but also according to its internal specific features (more focused perspective than in other European countries, which integrate SE with social economy), the Italian movement has engaged over time in refining theoretical approaches and experimenting with practices [142]. Its aim is to contribute to the development, diffusion and consolidation of an alternative, ethically oriented economic model within a more general perspective of societal transformation. The principles of solidarity, reciprocity, participation and inclusiveness allow for the redefinition and sharing of values within but also outside the market, supporting balanced growth, empowering communities, increasing democracy and spreading common good logic [55-58,142]. In this perspective, economic activities and social living are also guided by a sense of respect for the planet and its boundaries.

In operational terms, the main objectives guiding SE networks during their evolution can be summarised as follows [58]:

- Development of local SE systems, through alliances between actors and social networks committed to building sustainable socio-economic models for their territory (these projects have taken the name of Districts or Networks of SE);

- Development of a new culture of business, active citizenship, social solidarity (locally and between different territories/worlds), a new sense of responsibility in consumption practices, which are socially shared, so as to overcome the limits of individualist critical consumption, a different way of relating to environmental resources, a new dimension of community;

- Taking on a more direct "political" role, aimed at promoting systemic transformation processes, alongside the implementation of innovative production-consumption models, entering all public spaces for debate and decision making, on a local and wider scale;

- Interaction and cooperation with other organisations, also involved in criticising the dominant system and developing alternative and transformative processes.

Under a worsening environmental, economic and social crises, these principles and objectives have taken on even greater significance and urgency for the movement.

\section{Methodological Approach and Conceptual-Analytical Framework}

Our analysis draws from the knowledge acquired over several years of research on the themes of SE, alternative/civic food networks and local food policies, as well as from the experience gained in directly engaging in a variety of related initiatives. We have been directly involved in the SE movement over two decades of activism, participating in its international-, national- and local-scale activities). At the same time, we have played the role of "food citizens" within these networks (we have all been actively involved in a GAS for about twenty years, respectively, in Northern, Central or Southern Italy; for about ten 
years, one of us has been an active member of a CSA, based in Tuscany, Central Italy). This long and diversified experience have given us the chance to understand in-depth the features and dynamics characterising the movement in Italy, to appreciate the most significant developments from North to South and to follow the internal debate, centred on the issues dealt with in the present paper.

Looking at these networks and related initiatives from a constructionist perspective [143-145], observing and experiencing them from within and in this way following their development over time, has allowed understanding their deeper meaning and potential. This profound and continuative involvement has allowed conducting longitudinal studies [146] of several initiatives, looking into the daily life of the movements and performing some ethnographic research $[147,148]$. Due to our direct engagement, our work often took the form of participatory action research [149-151]. Instrumental to this qualitative methodological approach $[145,152]$, our researches methods included in-depth interviews, focus groups, online surveys, consultation of internal and published documents (including materials published on websites or exchanged by e-mail) and extensive participant observation at various scales and dimensions.

The above research approaches have also influenced how this paper is structured: we chose to give adequate space to the object of analysis, without overwhelming it with too much conceptualization, nor with sophisticated and/or original theoretical-analytical frameworks. We believe that the lens of innovation capacity and transformative potential emerging from civil society responds perfectly to our interpretative needs. For this reason, we have chosen a "social innovation" framework as the guide for our analysis, complementing it with other perspectives, which, as inherent in the innovation effort itself, have resulted in being useful to the scope.

Among the many readings of the social innovation concept, we have referred to a comprehensive approach that considers it as a process of change: (i) aimed at responding to social demands and societal challenges not fully satisfied/faced in alternative ways, via market or state intervention; (ii) grounded in existing social relations and, at the same time, capable of developing into new forms of cooperation; (iii) aimed at pursuing a social purpose, achieving social benefits [153-157]. This way of conceptualising social innovation considers it as leading to institutional change, referring to the regulative, normative or cultural structures that can be influenced by social groups engaged in developing new views and practices [157]. This concept of social innovation also emphasizes the role of social interactions and of changes within social relationships in terms of empowering social processes [153,154]. These processes may support meaningful growth of collective agency, social mobilisation and political engagement, which are important factors in processes of societal transformation [158]. In this respect, social innovation also relates to the relationship between the individual and society, namely the balance between individualisation and a sense of community. It allows focusing on the potential of socialised reflexivity, collectively shared sense of responsibility and collective capacity to mobilise, overcoming the dimension of personal responsibility/agency of the neoliberal perspective. Concerning the purpose underpinning this innovation, it builds on an idea of public good [157], of a process aimed towards public rather than private value creation $[153,154,159]$. Such a conception of social innovation and, within it, of the role of civil society implies a necessary redefinition of the relationship between policy and the "new power of the citizenry" ([160] quoted in [161]). The attention to the inter-relation between political institutions and social innovation and to the wider role of social innovation in relation to systemic change is the core of the "transformative social innovation" theory [162]. Such an approach defines social innovation as a "process of change in social relations, involving new ways of doing, organising, framing and/or knowing, which challenge, alter and/or replace established (dominant) institutions in a specific socio-material context" [163] (p. 8).

The theoretical-analytical perspective of social innovation helped us unveil the transformative potential of the grassroots innovation dealt with in the paper, which takes on an even greater significance when looking at the role of society in new governance ar- 
rangements. We have, however, complemented the framework of social innovation around food with other meaningful frameworks, which capture the need for redefining roles and meanings around food practices. These frameworks have shown strong interlinks over time and, indeed, are part of the social innovation process. The first is the food citizenship framework [112-114], namely the active citizens' engagement in food-related matters, the potential of which is increasingly associated with socially shared processes of awareness raising and empowerment [22,31,120-122]. This "collective food citizenship" has proven to be a powerful dimension for two reasons. First, looking at consumer citizens, it overcomes the trap of individualisation of responsibility/agency of the neoliberal perspective (reflected in the simplistic reading of the political consumerism by much literature). On the contrary, it assumes processes of empowerment that allow individual actions to become "individualized collective action" [164] (p. 24). This condition is more protected from system appropriation and co-optation and, at the same time and in a circular way, more effective in terms of collective political action. This is the outcome that Holzer ([165], p. 411) describes as "collectivized individual action". Second, collective food citizenship strengthens the convergence and engagement of different actors (rural/urban, producers/consumers) around a common role and a new politically oriented approach to food and the transformation of practices.

We also used elements of the food sovereignty framework. Originally promoted by the peasant movement $[166,167]$, it has over time been more broadly adopted by all those civil society organisations claiming for a model of food system alternative to the industrial and globalized neoliberal model [116-118,168]. In its evolution, within an emerging urban-rural dialogue, food sovereignty has come to involve both rural and urban realities, which have become allies around shared goals and struggles [169]. An aspect related to this broader conception of sovereignty is also overcoming the narrow condition of consumer's sovereignty, as it has been said above, instrumentally placed into the individual consumption-aimed sphere of action.

Both these manifestations of increasing the need of emancipation and self-determination around food matters are in turn linked to a growing willingness of re-signifying food in terms of "commons", as an expression of the re-appropriation of a good and re-affirmation of a right. This is another perspective that we have considered useful to capture the transformative potential emerging from the SE movement, associated in particular with the social and political dimension underpinning its actions and aims. It refers to processes of "re-commonification" of food and food systems as opposed to the "commodification" occurring in the corporate agri-food system under the logic of profit maximization $[105,106,170]$. Even more effectively, the concept of "commoning" captures the engagement of social systems in recognizing the values of food-related resources and cooperating to manage their production and reproduction in sustainable and democratic ways [105,171,172]. This emerging framework, which focuses on the changes occurring in food-related resources and practices and on the modes of their management, embraces the whole food system and addresses the entire society, opening a broader dimension of food system transformation.

In such a process of re-socialisation and re-politicisation of food issues, based on the recognition of the social values of food and food systems, a new configuration of roles and relationships among the main actors of a democratic food governance emerges [22,173]. This type of initiatives foregrounds the willingness and potential for change in the segments of civil society and in the production world: starting from an alternative conception of food, they are able to build alternatives practices and demand for broader change. These social instances also highlight the role of public bodies, in terms of the implementation of policies and creation of an enabling environment for the innovation potential of the new approaches and practices. Both these aspects can contribute to define a new food governance [22,173], more balanced in power relationships and re-grounded in terms of objectives. This process, however, is not without difficulties, because of the diversity of approaches, interests and values it mobilises [45]. All this constitutes another field of 
theoretical debate and political/institutional experimentation on which we have drawn for our analysis.

\section{The Specific Features and Evolution of the Pathways Inspired by SE Principles}

The many initiatives developed around food in the context of SE are characterised by the strong value component and the political dimension that underlie the search for alternatives in production/consumption practices and exchange systems. These features are at the basis of the growth of the mutual involvement and commitment of the parties that has occurred over time, consistently with the taking on of a common responsibility around food-related resources; this shared engagement has also translated into a stronger community dimension. This trend is consistent with the radical innovation nature of these initiatives and with their being inspired by a perspective of common good. In this section, we focus on these aspects, by referring to some meaningful examples taken from the wide range of initiatives that are carried out in the country.

A first manifestation of the above-mentioned growth of mutual commitment and responsibility is the deepening of the direct relationship between producers and consumers that characterises the GAS experience, already based on value sharing. Based on the recognition of some degree of weakening of the original transformative character of the model, due to its increased popularity and the entering of people less conscious, the need has emerged to strengthen the relationship through a more profound community-type model and a greater commitment of the actors involved to re-signify the interaction. There are many examples of this process:

(i) The development of "pacts", i.e., agreements established between producers and consumer networks around the provision of specific products. They are based on transparent and fair pricing (through a collective process of price-setting, based on calculation of production costs, including also business risk sharing), planning of production (based on consumers' commitments to buy) and pre-financing (through advance payments). Some pacts are already in operation, while others are being defined and implemented. They involve networks of GAS that are particularly committed to establishing closer relationships with producers and at the same time more "politically" oriented towards common goals, as detailed later.

"The 'Adesso Pasta!' project is the result of the cooperation between La Terra e il Cielo, an agricultural cooperative located in the Marche region (Central Italy), producing high-quality organic pasta, and 50 GAS equally distributed between seven regions of Northern and Central Italy. The project was designed through a participatory process started in 2009, aimed at defining all the operational and financial aspects related to wheat cultivation/processing and pasta distribution and at creating a fair supply relationship, inspired by the principles of price transparency and fairness of payments. In 2010, the parties established a formal agreement-a 'Pact of SE'. It provided for a commitment to purchase a certain amount of pasta during the year, partially paid in advance, at an agreed price; moreover, a small percentage of the price (involving producers and consumers equally) would be set aside into a fund to support SE projects (Solidarity and Future Fund), not necessarily to be carried out in the cooperative's territory" (authors' case study, 2017).

(ii) The more complete "food co-production dimension" implemented through the community-supported agriculture model (CSA), which represents the most advanced form of mutual commitment between groups of consumers and farmers. Consumers are engaged in the farm activities (planning, sometimes fieldwork and often care of the distribution activities) and participate in its economic risk. The focus of CSA is on a community dimension and a condition of interdependence, and the purpose of the alliance goes beyond a market relationship. Many of the initiatives indeed stem from the desire to overcome the shortcomings of the GAS experience and the consequent dissatisfaction of some members. 
"CSA means that the actors involved agree to share the risks of the farming activity, financing the productive season in advance, receiving the end products in return, in a quantity depending on the year harvest. Everything starts from the strong will to overcome the current market paradigm, which sees the producer on the one side and the consumer on the opposite, in an interaction mediated only by market rules. At the basis of that choice is a will to imagine and practice an alternative production and more in general economic system, which provides for an exit from the market and therefore a distance from the conception of the price of food as the only significant value" (Final document of the first national meeting of the Italian CSAs, June 2018).

(iii) The Participatory Guarantee Systems (PGS), which represent a self-certified system of organic products jointly managed by producers and "co-producers", that is, (organised) consumers involved as peers around a shared responsibility [174]. This model emerged as an alternative to the conventional organic certification system, considered an expression of the co-optation of organic agriculture by the mainstream food industry, and is shared internationally as a political project instrumental to food sovereignty [175]. Within the communities where it is adopted, it acts as a regulatory mechanism, instrumental to the internal governance based on shared principles and norms.

“How can Participatory Guarantee System (PGS) help rebuild communities? They are carried out by groups (including producers and consumers) that share a common value system. Factors that influence producers' choices: not so much profit maximization, but social rootedness and territorial care. PGSs emerge in Alternative Food Networks, and in fact they have worked where there is a strong alternative food network" (presentation of the research on "Lombard PGS" at the national meeting of the Italian network of SE in 2017 [176]).

Even more significantly, an effort emerges to integrate linear processes connected to local food provisioning with circular solidarity economic circuits, or food practices with other actions. In the first case, the aim is amplifying the mobilization and sharing of flows of knowledge and values together with those of goods [177]. By initiating interactions with other similar or complementary experiences at territorial level, new social structures emerge around collective objectives, such as the shared commitment to a model or the defence of the land or food as commons [178]. Examples are:

(i) The additional solidarity mechanism integrated in the "pacts";

"The Chart of the Italian SE network indicates 'the use of profits for purposes of social utility' as one of its own characteristics. The cooperative and the mutual relationships that involve producers and consumers do not only consider the definition of transparent costs, a fair price, the sharing of business risks and a pact of solidarity, but also takes into consideration putting aside a percentage of both producers' revenues and consumers' expenditures. This share should permeate every SE project to feed a common Solidarity and Future Fund, designed to support people who are going through emergencies or difficulties and also to support SE itself, in its ordinary actions and/or in new projects and practices" ("Fund of Solidarity and Future" in www.co-energia.org; accessed on 10 March 2021).

(ii) The implementation of community exchange systems (CES), inspired by solidarity and ecological ideals alternative to conventional monetary or bank systems (such as time banks and different types of local, community and complementary "currencies");

“(...) the reconstruction/construction of community spirit and community relations emancipated from the logic of interest are probably the only chance to remedy the ecological, spiritual, material and economic failures produced by a system that has devastated nature and the sensitivity of men and women closely linked to it. Starting from an idea of 'we' is urgent and indispensable; it is the 
first step to face the economic, social and ecological disasters in which we are living" (from the document: "A Community System of Exchange, to re-build the economy of places in transition, through resilient and supportive community ties" by S. Venezia-CES “Mi fido di noi" promoted by DES Brianza (Lombardy, Northern Italy)).

(iii) The community-based experiences that develop as forms of resistance to certain choices by local administrations considered unjust, such as those concerning land-use planning or allocation of public assets;

"We are a widespread community of citizens who oppose the sale of the Mondeggi farm, a public estate located in the municipality of Bagno a Ripoli [in the province of Florence]. We adhere to the concept of 'land as commons', for food self-determination through agroecology and free sharing of knowledge. We work for the diffusion of a small-scale, local, sustainable and subsistenceoriented agriculture. We decided to create a community to collectively address the various issues related to the land and its responsible use" (https: //mondeggibenecomune.noblogs.org/chi-siamo/; accessed on 12 March 2021).

Other pathways have developed around the principle/objective of social justice, with the aim of actively intervening in situations of social disadvantage, exclusion or distress. This is expressed by the many initiatives for inclusion and integration of marginalized groups, through ensuring the dignity of their work and respect for their rights, as well as for overcoming "food poverty" — the quality and quantity of food consumed by the poor and the "new poor". The principle of the right to food as a fundamental human right is central here.

"The SOS Rosarno project was established in a Southern Italy region, Calabria, characterised by a plentiful production of citrus fruits but also a complex social environment, dominated by phenomena of illegality and corporatism. In this situation, from the campaign 'Squeeze citrus fruits, not migrants', a network of small producers and citizens established around the shared aim of fighting against the exploitation of immigrants in citrus harvesting operations. From this experience, a mixed cooperative of Italians and Africans-'Mani e Terra' - was born, for creating legal work opportunities, in a land where social injustice and exploitation prevailed. The cooperative products, which are obtained under organic farming, are sold at a fair price directly to Solidarity Purchase Groups in many Italian regions" (https:/ / www.sosrosarno.org/; accessed on 20 November 2021).

The issue of food poverty is a growing problem in Italy, exacerbated by the COVID-19 health crisis [179]. Despite the emphasis in public documents on the "right to food", the question has so far been addressed by public policies through contrasting actions of a conventional type, including charity interventions, with a strong presence of the "private social sector" (soup kitchens, distribution of food parcels, home care for the elderly). Some interventions aim at creating synergies with food waste management, which is also tackled under a conventional approach. In the absence of more advanced public approaches, circuits of SE have carried out their own initiatives, combining solidarity and justice, sustainability and inclusion, support and emancipation, and inspired by the "right to food" as a priority and by the desire to also tackle immaterial poverty.

"The subject is particularly felt [in the Corsico area, in the province of Milan] because of the economic problems experienced there. [...] This is why the 'Local Food Poverty and Food Policy' project was born. It involves about 30 disadvantaged families from the Corsico area in a process of awareness raising and good food practices. Every week, local and organic products are donated to these families. Thanks to a collaboration with the small producers of the Parco Agricolo Sud Milano, the products are purchased at cost price with project funds [...] and thanks to consumers' donations through the mechanism of the 'available box' 
('cassetta sospesa'), envisaged for people who would not have access to it. A nutritionist guides families to choose healthier food and cooking workshops show them how to cook in a healthy way, avoiding waste and minimizing expenditures. In the future, a course on vegetable cultivation is planned" (authors' case study on 'BuonMercato' - Centre for Initiatives of SE of Milan area; September 2020).

The social dimension and the idea of food justice inherent in food practices were also evident in the many initiatives activated in Italy during the COVID-19 crisis, aimed at practising solidarity and giving continuity to food practices through these circuits, penalised by public provisions, but also involving new people in need of help [180]. Even under the imposed conditions of physical distance, SE networks have been proven to be able to promote and support the growth of social connectivity.

Over the course of the years, the desire to "re-socialise" food practices together with the will to create an alternative economic model has also translated into an effort to develop a model of community-embedded enterprise, according to a logic that prioritises social and environmental values. Not all of the pathways undertaken so far proved durable over time or were successful: some came to an end because of organisational fatigues and some were co-opted by market logics. Others are still managing "their market" autonomously, remaining faithful to the founding principles as well as robust in their innovative organisation. New initiatives are also emerging. The refinement and consolidation of this model is currently one of the greatest challenges the solidarity movement is facing; indeed, it represents another significant space for experimenting alternatives and supporting broader system transformation.

“The cooperative AEQUOS (Equitable Sustainable Solidarity Purchasing-https: / / www.aequos.bio/; accessed on 10 October 2020) has been operating since 2010, distributing organic food to about 1250 families located in 140 municipalities across 6 provinces of the Lombardy and Piedmont regions (Northern Italy). It involves more than 35 Solidarity Purchase Groups and 5 social and community cooperatives in its activity. The efficient management carried out over the years by members has made it possible to make agreements with producers who are guaranteed the purchase of a certain share of production at an agreed price, on the model of CSA. AEQUOS gives producers $85 \%$ of its turnover" (authors' case study, July 2020).

"Camilla is a cooperative in which all members devote a share of their time to the management of the community emporium. The members are the only owners, managers and customers of the emporium. All activities are carried out by members on a rotational basis, each working three hours per month. The cooperative, established on 21 June 2018, buys from suppliers selected by the members on the basis of product quality and sustainability of production. Camilla supports peasant agriculture as an alternative to industrial agriculture because it respects natural balances. Thanks to self-management and direct purchase from producers, the cooperative guarantees all members the possibility of buying high quality goods at low prices while respecting the fair remuneration of those who work." (Alchemilla, GAS of Bologna co-founder of Camilla, 2019).

Finally, an increasing willingness to take on a more direct political role is leading SE networks to try entering public spaces of debate and of decision making, on a local and wider scale. The aim is twofold: (a) to make their vision, principles and patterns more visible and effective, reinforcing the public discourse around food meanings and practices they have already contributed to develop and paving the way to a more generalized reconnection, re-localisation and re-commonification of food practices; (b) to leverage this discourse and to influence politics. Examples are:

(i) The recent participation in campaigns and in the public debate about topical issues, such as the rights of small-scale farmers and the legal recognition of family based agriculture (in Italy a process on these issues is underway in Parliament); the adoption 
of a transformative approach in reforming the $\mathrm{CAP}$ or in the aspects concerning agriculture within the Italian post-COVID recovery plan; the issues of food sovereignty and food democracy.

"The time has come to demand that farmers and citizens be allowed to make real choices, and that the role of policy in defining the real costs of different production models be recognised. Now, this vast movement calls on the institutions to remove the many regulatory obstacles that have slowed down its growth so far, to ensure that agricultural policies are designed to support what is beneficial to communities, and to enable people to make useful choices for the environment, health and social equity, promoting access to nutritious food and a capacity to recognize unhealthy options. Today we demand active support starting from the recognition of our practices; we demand political and physical spaces to multiply the examples of virtuous, fair and sustainable production systems; and an agricultural policy that actively supports them." (from "Food sovereignty project in the Emilia-Romagna region. Changing agriculture to change the world", collective document produced by Campi Aperti-Association for Food Sovereignty, Arvaia-CSA in Bologna area, and Camilla-Food Coop in Bologna, 2020).

(ii) The search for interactions with public authorities to manage specific activities (e.g., access to public lands, food provisioning through alternative channels under the COVID restrictions).

During the first lockdown, the Italian Network of SE produced guidelines and documents that could be used by local networks to interact with public authorities. In Tuscany, an informal coordination of the movement demanded the Regional Government and the Tuscan section of the Association of Italian Municipalities (ANCI Toscana) to intervene in support of local, alternative food circuits, stressing the social value of these realities and the right of producers and consumers involved in them to be legitimated in their choices.

(iii) The involvement in debates on the critical features and vulnerabilities of the mainstream food system (particularly as uncovered by the COVID pandemic) and in initiatives concerning the definition and implementation of local food policies for more sustainable food systems.

In addition to emphasising the right to get involved in alternative forms of food provision during the health emergency, the Tuscan SE movement also demanded a public policy commitment for a real socio-economic change and requested access to food governance spaces. As a result, at the beginning of 2021, ANCI Toscana invited the movement to find a spokesperson to be included in a committee on regional food policies.

"Against this backdrop, the need to adopt a different vision and to consolidate, experiment and disseminate alternative practices has become evident, so that the recovery of our social life and our economy does not turn into 'business as usual', but is based on new principles, priorities and objectives. The terrible experience we are living can represent an opportunity if we are able to catch and manage it." (From the letter to the Tuscany Government President, June 2020).

In the Veneto region, in the first months of 2021, the local SE networks sought for dialogue with the Regional Government, to ask for institutional space to define new food policies, in particular oriented to support "local, sustainable food networks" (including the alternative food networks adhering to the movement). They demanded for an integration between a renewed vision of the food system and a more sustainable and socially just overall development model (referring to the national recovery plan under finalisation). Again, the demand for adequate food policies is framed in themes of food sovereignty and democracy.

In Emilia Romagna region, in May 2021, the "Network for Food Sovereignty in Emilia Romagna" was established, as an outcome of the project promoted by the three organisations above mentioned-Campi Aperti, Arvaia and Camilla. Emilia Romagna is 
one of the three Italian regions where the movement succeeded in obtaining the enactment of regional laws recognising the SE movement and introducing specific institutional tools and spaces for policy interaction. Within this context, the broad network means to act as a political actor to influence the regional public policies related to food. The objective is promoting a new model of production and consumption based on the principles of agroecology, supporting peasant agriculture and solidarity economy initiatives.

Regarding the SE movement's participation in specific pathways towards urban food strategies, the outcomes have been different so far. Some of the initiatives-such as those in Pisa, Milan, Livorno and Trento-have not been particularly encouraging: they did not succeed in involving grassroots movements, often for lack of willingness of the movements themselves, in part for methodological shortcomings in their approach $[59,60]$. Other initiatives (Bergamo, Roma, Lecce, Matera, Venezia, Treviso), most of which benefited from past experience in this kind of process, seem to be more promising, as the SE movements are currently interacting with public actors $[60,61]$.

\section{The Origin and Potential of the Search for "Other" Food Systems}

Grassroots initiatives around food inspired by SE principles are a significant expression of social mobilisation and re-organisation towards new approaches and practices. According to the conceptual frameworks we have adopted, these initiatives can be identified as "social innovation". They are processes of change that (i) arise from shared needs of certain segments of society, not satisfied by the dominant system in its components of market and public intervention, (ii) build on social interaction and cooperation as spaces and means to seek/develop alternatives, while at the same time nurturing empowerment processes and (iii) pursue social benefits. Significant distinctive features of these experiences match these three components of social innovation: the sharing of different sensitivities, needs and aspirations around food-related practices; the collective process of refinement of values and cultural frames, the definition of new norms and rules and the experimentation of innovative practices; the importance of social relations as space of individual growth and development of collective agency to support innovation and transformative action; a holistic approach, based on the recognition of the multiple dimensions of food, the adoption of a collective-solidarity perspective and the search for public value. These aspects, as discussed, lie at the basis of the willingness and capability to build alternative pathways. They also express the potential to generate wider change in the dominant system (the transformative potential of this grassroots innovation) [162], based on the capacity to give voice to wider societal needs and to prefigure new cultural, social, technical, economic and institutional solutions.

In a perspective of needed transition towards more sustainable systems and of a growing interest in local food policies [51], the innovation that these experiences bring provides important elements for reflection. In the following sections, we will analyse the significance of these experiences with regard to the above-mentioned components of social innovation. In Section 6, we will discuss their contribution to the development of local food policies.

\subsection{From New Sensitivities and New Needs...}

These grassroots innovations reject the commodification of food and express the need for a change in the values embedded and transmitted in and through food.

A first element at the basis of the construction of alternatives is the search for foodrelated health both for food actors and for the environment (pursuing values such as food safety, nutritional content, environmental sustainability), combining functional and ethical needs. This quest implies favouring organic or biodynamic agriculture and, increasingly, an agroecological model, considered not just as a possible option to be evaluated if economically advantageous, but rather as the only solutions enabling sustainable farming and healthy eating. The preference for as much as possible unprocessed food and the greater consideration for food value (minimizing waste) go in the same direction. The same applies 
to the preference awarded to local production and distribution systems, an alternative to global food supply chains. The SE movement integrates all these aspects into their overall system of rights, sovereignty and democracy, as well as in the complex power dynamics that underlie the food system structure. While these features have long been considered by practitioners, scholars and policy makers as mere expressions of ideological positions, they have more recently started receiving greater recognition as concrete pathways for change by public and private institutions and research institutes [see references mentioned in Section 2.1].

Another value-based need to which these initiatives respond is that of social justice. This need is inherent in the construction of equal and fair relationships within food systems (among supply chain actors and between producers and consumers) as well as in the preference for producers marginalized by the dominant system (small-scale, "irregular" farms). Over time, it has also found expression in the attention to farm capacity to take on new social functions (such as the inclusion of disadvantaged people) and, more recently, in forms of solidarity with other consumers, beyond the purely welfare-based approach of public or private institutions (such as the one carried out to face the poverty problem, including the worsening of the situation during the pandemic) [180]. In general, the growing attention paid to food justice issues is a significant feature of the evolution of SE networks' initiatives. It is contributing to redefine the discourse on access to the food system and food, shifting the perspective from the dimension of "need" (the state of farmers" inadequacy or consumers' indigence), to that of "right", thus amplifying its significance in social and political terms.

The cultural leap when conceiving the above-mentioned aspects is extremely significant. It leads to entirely redefine the value of food and related practices on the basis of a holistic set of values [31], overcoming the narrow range of use and exchange values of economic liberalism. Although these values are only partially translated in monetary terms, they contribute to deeply reshaping market exchanges around food. The search for equal supply chain relationships includes a different approach to value distribution along the supply chain and to the definition of price of final products, which builds on fairness and sustainability criteria. In particular, the price of agricultural products takes into account all the specificities of production systems (production methods and areas, small scale, possible lower efficiency, etc.) and, more in general, is related to the social and environmental functions of these systems. The price of food is associated, as far as possible, with the multiple values food incorporates. It is far from the meaning and use it takes on in the competitive market strategies of corporations and in the "financialisation" of food on global markets, where food is handled as a commodity to generate profits. In this perspective, food price is a real signifier of meanings and choices and conceived as such in the exchange relationships. For consumers, its redefinition and acceptance are expression of the collectively revised conception of individual utility that takes place in these relational spaces and is inherent in their commitment to contribute to food de-commodification. The same approach permeates the management of payments: despite the diversity of modes among the various initiatives (among GAS and among GAS, pacts and CSA), payment follows a different logic compared to the conventional system. It is based on the recognition of the value of farmers' work, but it also takes into account the financial aspects and risks of the production activity. Further innovative elements of solidarity intervene when the relationship between producers and consumers takes on more advanced forms of "social pact" [181]. In addition to the strong mutual commitment around a collectively managed crop/food system, the monetary value exchanged foresees an additional share devoted to supporting SE initiatives, thus feeding other value flows out of the market.

A more general need driving the search for solutions out of the system is that of self-determination, autonomy and sovereignty, consistently with each individual's value base, both as producer-citizens and as consumer-citizens. In particular, such a need expresses the desire to go beyond the mere "consumers" status as well as beyond the limited consumers' freedom of choice among the few options provided by the dominant 
market and the condition of individualised responsibility. Based on a socialised process of contestation and "re-appropriation" (of meanings, values, aims), this need implies more: a meaningful, collectively supported empowerment, a capability to self-organise comprehensive alternatives to fully exercise the right of choice and the search of new forms of political engagement to claim for food democracy and food sovereignty.

\section{2. ... through New Interactions and Empowerment...}

The recognition of new values in food and practices develops within social relationships. At the same time, this increases networks' and communities' capacity to look for, build and share social values, in a process of mutual reinforcement. In other terms, social interaction and mobilisation are crucial to food re-signification and this resocialization of food is functional to community consolidation and societal empowering.

The priority given to the relational dimension as an area of emancipatory growth, sharing and co-construction of alternative approaches is indeed a distinctive element of these initiatives. It concerns the relationship between producers and consumers but, more generally, the social relationships that are mobilized around food and related issues. This is consistent with the weight of the value component, which sees the interpersonal exchange as a privileged channel and the social dimension as a space of interaction where common normative frames can be defined and translated into shared norms.

The construction of close and equal relationships between producers and consumers is based on the willingness to redefine the relationships between the two parties, overcoming the traditional separation (and related competition) imposed by the market. This finds the most advanced expression in the CSA model where, in a condition of "interdependence", the parties are equally involved in the farm management (mutual commitment, sharing of the economic effort and risk), which is in turn considered embedded in the community. This is a real disruption of the dominant market logics. A further challenge in this sense occurs when some practices are kept out of the market, through consumers' voluntary involvement in carrying out some producers' / vendors' activities (as occurs in GAS, CSA and food coops). The sense of social justice and the "solidarity" logic (in the original sense of cohesion, based on being part of a "community" engaged in a common project) influence consumers when choosing their allies. They establish relations as a priority with producers who do not have access to the dominant food system (because they are too small and /or do not have the necessary organisational requirements), with "clandestine" or "out-of-standard" realities (which do not comply with official standards), or with production entities that are open to adapt their internal organisation, for instance including disadvantaged groups.

Solidarity value informs relationships with other consumer-citizens as well, where it allows taking into account diversity of knowledge and/or economic (purchasing) power. The latter is expressed by alternative solutions to assure access to the monetary exchange, e.g., flexible pricing (in relation to economic possibilities) practiced in some GAS and CSA, or the previously mentioned solidarity practices to tackle old and new food poverty. The COVID pandemic and its economic consequences have brought the problem to the fore and favoured the multiplying of these initiatives. In this context, the right to quality food becomes a matter of social justice and, thus, an object of solidarity, not left to be regulated only by the rules of market exchange. More generally, the potential of relationships finds expression in the development of collective agency, which goes beyond the dimension of alternative practices, generating forms of civism and political mobilization capable of making a further contribution to the satisfaction of justice needs emerging around food. Examples are specific projects such as the previously discussed "Local Food Poverty and Food Policy" project of the Lombard Corsico area or initiatives of resistance against public decisions that counter food sovereignty rights.

The social learning that develops through the interaction between actors involved in these experiences as well as within their broader networks is fundamental. It supports the development of sensitivity, awareness, shared knowledge and new social norms that 
lead to the development of new social practices and consolidation of collective identity and agency [31]. These processes allow producers to deal more easily with the transition to alternative models of production and marketing, in terms of attitudes and skills, and more in general to redefine their social positioning [130]. On the other hand, consumers are supported in the growth of their capacities and role, in their "reconnection" to food going beyond the dimension of critical consumption and rather adhering to a more significant collective project of transformation. Both producers and consumers are accompanied towards a socialized dimension of food citizenship, in which political awareness around food issues is also developed [22]. In this sense, belonging to SE networks at any scale provides a meaningful social environment, which enables processes of emancipation and empowerment, both at the individual and collective level, paving the way for more durable and significant changes and nurturing a broader transformative potential.

\section{3. ... towards a Redefinition of Food and Food Systems}

These experiences clearly conceive access to "good" food as a right and extend this right to the entire "food system", with reference to all the components involved (going beyond the rhetoric that characterises the narrative on the right to food). This is associated with the recognition of the multidimensionality of food and, therefore, the multiplicity of its values: food is not only an essential resource for life but also carries social, cultural and ethical values, including fundamental elements of social life. Manifestations of this food composite value are: the individual well-being; the community dimension, sociality and social capital that are (re)generated around a different approach to food; the reproduction and valorisation of diverse knowledge resources; the recovered autonomy in choices and practices, both in producing and consuming; the responsible relationship with natural resources and the production of ecosystem services; the respect for the dignity of labour and consumption. This vision shows to overcome the private-utilitarian dimension that often characterises market-based relationships to embrace a communitarian-mutualistic approach to food, aimed at common well-being. In this logic, these experiences look at food not as a commodity to be managed on the market by means of its conventional mechanisms, but as a commons, an essential resource whose signification, production and reproduction involve all members of the community and make a larger set of social benefits available. This perspective deeply informs the narratives and practices that the actors of these initiatives share, as well as the other initiatives and related narratives that develop within broader networks. The campaigns and debates organised around the themes of food sovereignty, the right to land and food, the need for a radical change in lifestyle and economic models, social inclusion and environmental justice mirror this shared horizon.

The approaches and practices underlying these initiatives also reflect a systemic vision and a paradigm shift. This vision is inherent in the ultimate aim of redesigning the "development" of our society on an alternative basis with respect to the capitalisticneoliberal model, according to a vision that prioritizes living beings, their needs and rights and their balance with the environment. Aiming at a transformation of food practices and food systems according to principles/objectives of solidarity, environmental resilience and sustainability, fairness, inclusiveness and democracy, these initiatives prefigure an agroecological transition where environmental, social, cultural and political determinants prevail over economic logics.

\section{What Contribution for Innovative Local Food Policies?}

We have considered the experiences of food networks inspired by SE principles an advanced manifestation of societal willingness and capacity to generate change. These experiences provide many elements to be taken into account to develop innovative local food policies, capable of promoting processes of ecological, cultural, social and economic transformation of local food systems and contributing to a wider transformation of lifestyles and economic systems $[80,173]$. Evidence has so far shown that the potential for 
transformation of these experiences, although widely recognised, has not yet been fully picked up by public policies.

First, the significance and urgency of a "re-commonification" of food and food systems emerge $[105,170,172,182]$. By redefining modes, relationships and aims involved in the management of food-related resources and practices, SE experiences express the willingness of a segment of society to re-signify food value and to rebuild a completely different system. In a social and cultural context wider than a niche, this points out necessary, important transformations: the construction of a new awareness and the systemic diffusion of a different culture around food and food systems among citizens, enterprises and public institutions; a process of "de-colonisation" of food as a market commodity and reconstruction of a new social narrative around it, informing all spaces of action; the reintroduction of food issues within a political dimension. Public interventions to support adequate knowledge and narratives about food and coherent choices in policy practices could help to counter the cultural hegemony created by the marketing strategies of agrifood corporations and their commodifying effects. This counter-action could be extremely important in the face of corporations' capacity to exploit emerging societal sensitivities and claims, to ensure the maintenance of their supremacy. On a larger scale, a process of re-empowerment of society in its relationship with food could create the conditions for greater food sovereignty. This highlights the transformative potential of the challenge posed by radical grassroots innovations and the significant political meaning that "decommodification" and "commoning" processes take on [172].

As the many concrete practices and alternative discourses developed within these initiatives show, the construction of a new food culture should redefine all the valuable components of food. It should uncompromisingly support healthy and ecological dietary models, raising awareness on the critical aspects of current food models and encouraging the search for alternatives. It should make explicit and clear which types of agriculture and processing activities underlie each food product, unveiling technical, economic and ethical issues. It should also promote knowledge on the relationship of food with the local territory, highlight local production potential and favour linkages between local production and consumption systems, to the establishment of new supply chain relationships.

Re-valuing food and food systems also implies re-considering their social acknowledgement. Based on the recognition of food "values", the question of prices needs to be seriously tackled, making the degree of inclusion of positive and negative externalities explicit, to overcome the mismatch between price, value and social cost of products. Although there is now an increasing awareness of the need to look at the true cost of sustainable food, communication about pricing politics and price meaning is generally still lacking through conventional channels and is addressed legally even less. The related question of access to "good" food should be tackled rigorously too. This would require addressing the issue in a non-contradictory way (e.g., assuming prices on commodity markets as benchmarks) and in a non-simplistic way (using the rhetoric of keeping food cheap to guarantee wide access) [31]. As SE initiatives show, re-defining food prices is an essential step towards food de-commodification and re-commoning, which goes hand in hand with the increase in knowledge about food-related values and a normative reframing. At the same time, taking into account food accessibility demands a further advancement: being a fundamental human right, this should not rely exclusively on individual purchasing power, without any adjustment, thus favouring social inequalities [173]; moreover, the economic recognition of food and food system values should not be left only to market mechanisms. Both the aspects of good food accessibility and sustainability call public policies into play, with reference to the possible measures that could be adopted to appropriately manage the value of food and ensure its rightful positioning in social life. Possible measures could concern income, taxation, trade regulations, welfare and a more focused system of incentives and compensation in agriculture, achieved through an integrated approach. The policies should be complemented by massive public actions of societal education around food meaning 
and practices, coherently with the above-mentioned de-commodification and aimed at emancipation and empowerment.

The development and choice of alternative food models and, thus, the change in producing and provisioning practices demand first of all the creation of enabling conditions. Together with a different culture of food, these conditions contribute to creating a "food environment" where food practices take place. The grassroots innovations under study have reshaped both food culture and food environment to practice the change they advocate for. As already seen in part, creating an enabling environment for a broader societal change requires alternative and coherent choices in many public policies. Alongside education and public communication, policies concerning land use planning, agriculture, retailing, public procurement, social welfare and public health are also involved. All this calls for an integrated approach and a perspective of transformation, overcoming the short-term perspective and the narrow, sectoral view that generally characterizes the public administration.

Looking at consistency and effectiveness, radical grassroots innovations highlight existing bottlenecks in public policies that need to be solved in order to change practices. These include, for instance, the difficulties encountered by peri-urban agriculture, which often suffers from a lack of recognition of the value of agricultural land use or the obstacles to land access by new farmers (who have greater innovation potential). Another obstacle frequently complained about is the inadequacy of regulatory frameworks in recognising and legitimating very small production systems or those with special characteristics. Indeed, despite the importance attached to family and peasant agriculture by international policies and the widespread social consensus, political pathways towards a specific legislation on the subject have not been completed yet. Moreover, current agricultural policies provide measures that are often inaccessible to small farms. Innovative forms of cooperation involving producers and consumers often suffer from a lack of legal recognition. The multiplication of these initiatives and the weight they have been taking on in meeting food needs have foregrounded the need for an evolution of the juridical institutes and regulatory frameworks. The COVID pandemic has contributed to make the variety of solutions developed around food practices visible, together with their social value, putting the question of their legitimation to the fore. The contradictory or compromising positioning of public policies with regard to production-consumption models to support or prioritise (supermarkets vs. small-scale channels) represents a critical aspect. As mentioned, during the first lockdown, the SE movement denounced these choices, at the same time proposing alternative solutions by interacting with local public authorities at both national and regional levels. Apart from some tacit permissions to operate at very local levels, no significant formal initiative was kick-started.

A change in the general approach to the development patterns of agri-food system is presented as another significant challenge to be faced. Local food policies should reconsider the structural features of local food systems, taking into account the negative environmental, economic and social effects associated with the increase in scale (in turn driven by the logics governing global supply chains). Radical alternatives proposed by SE show a model of food system development that, rather than being based on mechanisms of scalingup, concentration and adoption of high-impact formats (e.g., large-scale settlements and related infrastructures), builds on a widespread proliferation and scaling-out of small-scale, ecological, diversified and locally adapted systems, rooted in social contexts. The success of this model, when it is well managed in technical and organisational terms (also benefiting from information technologies, as shown by many experimentations going on), testifies to its feasibility and sustainability and its effectiveness in valorising local food resources. Considering the challenges of the environmental crisis and the food system vulnerability to other shocks (as the recent health emergency), a significant transformation of the dominant system and the options prefigured by these alternative pathways of development should be taken into careful consideration. 
A precondition for the transformation of policies and their capacity to contribute to a food environment that enables change in food practices is the existence of a political willingness and an institutional culture capable of managing the complexity of this process. Within a global agri-food system that seems more solid than ever in its power and ability to adapt, the recent interest in food policies and strategies on a local scale have triggered an important process of innovation in this direction. In Italy, although it was the place where the international initiative of the Milan Urban Food Policy Pact was launched in 2015 (with 28 adhering cities to date), these pathways have started slowly and have not produced consolidated experiences yet. The willingness of actualising these instruments has recently been increasing; however, just a few food strategies (Milan, Livorno, Lucca, Camaiore) and Food Councils (Livorno, Lucca, Alto Adige) have been institutionalised. Other initiatives are still in the making or just starting (such as those of Torino, Bergamo, Trento, Roma, Matera, Lecce, Cremona). It is, thus, not possible to make an overall assessment. Looking at the documents that accompany the establishment of these pathways, there is generally an awareness of the value of innovation already initiated by segments of civil society and perception of the existing potential in terms of new consumers' sensitivity and favourable attitude towards new food practices. As the completed processes show, however, a true and systematic adoption of the innovation pointed out by grassroots initiatives within food policies is still lacking. In several cases, the pathways towards food policies seem just to express a willingness to include and support these initiatives, together with a partial and sometimes not very effective re-definition of policies.

Ultimately, the most significant challenge underlying the definition of new policies does not seem to be met. In addition to the need for willingness, determination and coherence, the need for a paradigm shift in how food systems and their management are conceived, in the direction prefigured by SE experiences, requires radical political choices, and to that end, a significant cultural leap. The narrative developed by SE networks clearly expresses this leap. It stresses the need to give priority to production-consumption systems that aim at food sovereignty and food justice and, to that end, foster growth of knowledge, shared responsibility, sense of community, citizenship, political awareness, inclusion and social justice around food. This is very far from legitimising a system based on the domination of private economic interests over those of individuals and communities and, therefore, favours the loss of knowledge and skills, reduction in freedom, individualisation in choices and practices, social alienation and denial of rights. In other words, overcoming the limits of the current system requires questioning its principles, rules and basic mechanisms, including the underlying power structures.

\section{The Inclusion of Radical Social Innovation in Governance Spaces}

A reorganization of policies and practices around food on a truly innovative basis builds on a different interaction between public actors, enterprises (market) and civil society, to guarantee a participatory and democratic definition of objectives and strategies and to make the most of the variety of available resources and efforts [22,108]. The variegated ongoing experiences at the local scale testify to the importance of cooperation between the public sector and those civil society initiatives engaged in food practices with a social aim [183]. The choice to consider food as a commons, to be managed through the involvement of the entire community, makes the implementation of adequate systems of democratic governance even more significant [105].

The pathways of social innovation launched by SE networks, as we have seen in the previous sections, constitute significant experience from which to learn with regard to the problems to be addressed, the objectives to be achieved and the areas and modes of action to be activated. These stimuli appear particularly important in a context that, despite an awareness about the need for a transition, often seems to be oriented towards compromise solutions [31]. Catching them, however, requires that the democratic processes aimed at redesigning local food strategies allow these networks to express their transformative potential, by providing an adequate environment. As we already asked some years ago [129]: 
how can this capacity for radical innovation and agency be integrated into effective modes of governance? The need arises for adequate approaches and tools to manage involvement and interaction.

The evidence shows the complexity associated with the enhancement of these initiatives in a political dimension. Indeed, public institutions' openness to any manifestation of grassroots innovation, their capacity to guarantee continuity of relationship and creating conditions for true participation in decision making can make a large difference. On the contrary, shortcomings in this respect may undermine the establishment of fruitful relations, in some cases leading to distrust towards public bodies [59,60]. On the other hand, these interactions may become difficult to manage because of the attitudes sometimes adopted by SE movements. The evidence shows that the political positioning of some social groups with respect to collaboration with institutions may hamper interaction, if not even lead some groups to exclude themselves from participation. This was the case in the process for developing of a food plan in the Pisa area [59]. This type of dynamics has also been described in other studies on networks pursuing models of "alterity" (alternative autonomous pathways) or networks oriented towards radical system change [184].

The existence of these factors and dynamics invite to a reflection on the ways by which governance space is managed. The choices made, both structural (in particular the governance institutions) and procedural (the management of the decision-making process), may significantly influence adhesion to the process by alternative food networks [59]. In this regard, it is clear that the traditional forms of civil society representation within public spaces are inadequate to capture a highly variegated landscape of social actors, instances and modes of political action. The evidence shows, for example, the difficulty of legitimising informal groups, as in the case of the interaction between public institutions and SE movement in Tuscany. In addition, there is a need for innovative spaces, mechanisms and methods for guaranteeing these social groups' active participation and enabling the expression of their actual and potential political role, empowering their transformative potential [185]. Important tools are represented by institutions of participatory-deliberative democracy, which guarantee openness and effectiveness of democratic decision making and, not less importantly, adequate methodological support to overcome the power asymmetries, communication gaps and barriers that characterise interaction in these arenas [59]. In that sense, the "multi-stakeholderism" in itself is not a guarantee of equal and fruitful confrontation nor of real equity in influencing decision making, as these depend on existing power relations and their capacity to influence the debate and final decisions. In the pathways towards the establishment of new governance settings, some promising cases testify to the importance of setting up informal spaces of discussion and co-planning, where public actors and civil society collectives can experiment with innovative institutional arrangements and practices. This is exemplified by some recently initiated pathways (e.g., Alto Adige, Lucca, Roma), which maybe have benefited from the collective learning about these processes that has taken place over the years. Finally, the coherence of the processes - continuity of involvement, outcomes of the co-decision process and actual achievements-appears equally important in order to avoid triggering negative social dynamics (e.g., disengagement, loss of trust), as occurred in the Milan case. Beyond coherence in managing structural and procedural components, however, what seems truly crucial is the existence of a shared vision about the social aims and public priorities to be pursued and a commitment in that sense. These aspects emerged clearly in the Pisa case, where the perceived inconsistent behaviour of the local administration led the SE networks to reject all forms of cooperation.

The stimuli offered by SE networks go beyond the local governance dimension. Based on their multi-scale nature-as networks engaged in local socio-economic systems but also working at the national scale and connected to global networks-they aim at triggering processes of systemic change and generating more significant processes of societal transformation. The initiatives aimed at establishing a dialogue with regional public authorities (e.g., in Tuscany, Veneto and Emilia Romagna) or the adhesion to national campaigns on 
food-related issues (e.g., small-scale/family farming, Italian contribution to CAP reform) exemplify a willingness to take on a political role at multiple scales. The same can be said in relation to SE movements' engagement in the European mobilizations that claim for a CAP reform in line with the European Green Deal and the Farm to Fork Strategy. In a framework of multi-level food governance, where the pathways implemented at local level can act as innovation niches to stimulate and orient change at higher institutional levels, the capacity to integrate the innovation potential coming from these networks represents a valuable opportunity. Local food policies could increase their potential as places for experimentation with innovative approaches, capable of contributing to wider impacts, in alliance with other movements and other realities (e.g., exponents of research and politics) working in the same direction. The creation of a debate on the opportunity of a national food policy and the pressure for implementing a progressive food policy at the European level [13] represent important areas of engagement in this regard.

\section{Conclusions}

The general aim of this paper was to contribute to the debate on the transformation of current food practices and systems. To that end, it analysed the radical innovation carried out by the SE movement, focusing on its features of social innovation and highlighting the challenges that it poses for the system to undertake a real transition. The analysis provided food for thought and indications for action.

The experiences around food inspired by SE appear as an advanced manifestation of civil society's awareness of the social and environmental failures of mainstream agri-food systems and reflect a willingness and capacity to build alternatives based on a different paradigm. As such, these initiatives pre-figurate possible evolutionary pathways towards more equal, just and sustainable food systems. At the same time, they show the need/opportunity to renew current governance configurations in managing foodrelated issues.

The lens of social innovation has highlighted how, based on a shared normative approach, these initiatives build their action on solidarity (collectivism and mutualism), which informs every aspect (learning, responsibility taking, development of agency). A social utility perspective, which pursues social values, is also very strong. Through all the above, SE movements re-significate food and related practices, create counter-narratives to the dominant ones and enact concrete alternatives, as well as develop a collective agency to consolidate and spread their innovation.

This grassroots innovation provides a representation of the embeddedness of the concept of commons in our society, as an ethical principle of organisation that structures every area of social and economic life, as opposed to the individualism, utilitarianism and profit maximisation that drive the neoliberal capitalist model. It builds on communities of practice engaged in taking care of what they consider precious goods (tangible and intangible). Moved by this sensitivity and will, they create social value within society, in the quality of the interactions that develop around these goods and in the distribution of the social benefits accrued. In the operational and "in the making" dimension of commoning, these practices appear capable of triggering collective processes of empowerment that allow people to acquire awareness and develop a greater sense of responsibility and commonality. On these bases, community engagement can lead to the redefinition of food and food system values as well as to the definition of the modes of use, production and reproduction of these resources.

All the above provides useful lessons, helping us to understand the mechanisms of societal change around food. These involve more complex, socially mediated processes of re-definition of the meanings and practices around food, rather than mere reactions to external drivers (being them information, education or incentives).

The capacity for radical innovation emerging from these civil society expressions challenges the responsibilities of the public sector in terms of normative reorientation, coherence and the effectiveness of policies. Legitimising these pathways and creating 
favourable conditions for their multiplication may be useful at the micro-scale of local food policies. They can facilitate a more general reorientation of culture and practices around food, as well as allowing experimentation with accessible changes. However, as we saw, the challenge is much more significant: in a perspective of transitioning to a post-neoliberal economic model [41], the true challenge is being receptive to this societal potential and to the imaginaries, mechanisms and goals of change pointed out. A deeper, meaningful system transformation, as SE initiatives call for, is a much higher ambition than a mere diversification of the system. This is particularly significant considering that several local administrations engage in constructing food policies by just focusing on or assembling single initiatives, in many cases not progressing much further than what is already in place.

New, significant challenges are also posed to the governance configuration, which is questioned in terms of: (i) Actor composition and related implications-what visions and what interests are at stake? (ii) Operational modes-what legitimation mechanisms are needed? What methods are best suited for a truly democratic interaction? (iii) Purposeswhat aims and what priorities should be adopted? As we illustrated, creating conditions for a "reflexive governance", redefined in its aims and tools, is much more than opening governance spaces to new actors and, based on the possibility of interaction, negotiating among different interests. Commoning of food-related practices as called for by this grassroots innovation extends to governance systems, requiring renewed roles for the public sector, civil society collectives and enterprises, which allow and call upon these actors to act coherently and cooperate to pursue shared public goals. Public actors in particular have the duty to create an enabling environment for this rebalanced and reoriented governance.

The institutional innovation represented by local food policies indeed offers a great opportunity for a broader social innovation around food: facilitating effective processes of re-politicization of food-related issues and opening to new visions and approaches can significantly contribute to a more general transformation of food systems. This article was meant to stimulate reflexivity on the implementation of this pathway, drawing attention to the need to keep the goals high and fully exploit the potential for change that exists in society. Further and more in-depth research is needed to implement this necessary monitoring and critical evaluation.

Author Contributions: Conceptualization, A.R.; methodology, A.R.; investigation, A.R., M.C. and D.B.; writing—original draft preparation, A.R., M.C. and D.B.; writing-review and editing, A.R.; supervision, A.R. All authors have read and agreed to the published version of the manuscript.

Funding: This research received no external funding.

Institutional Review Board Statement: Not applicable.

Informed Consent Statement: Not applicable.

Acknowledgments: We wish to thank the many people we met during our research activities on these initiatives and the organisations in which we are engaged for the opportunity they gave us to understand the observed processes from a broader perspective.

Conflicts of Interest: The authors declare no conflict of interest.

\section{References}

1. Hawkes, C. Uneven dietary development: Linking the policies and processes of globalization with the nutrition transition, obesity and diet-related chronic diseases. Glob. Health 2006, 2, 4. [CrossRef] [PubMed]

2. Popkin, B.M. Global nutrition dynamics: The world is shifting rapidly toward a diet linked with noncommunicable diseases. Am. J. Clin. Nutr. 2006, 84, 289-298. [CrossRef] [PubMed]

3. Vermeulen, S.J.; Campbell, B.M.; Ingram, J.S.I. Climate change and food systems. Annu. Rev. Environ. Resour. 2012, 37, 195-222. [CrossRef]

4. Monteiro, C.A.; Moubarac, J.-C.; Cannon, G.; Ng, S.W.; Popkin, B. Ultra-processed products are becoming dominant in the global food system. Obes. Rev. 2013, 14, 21-28. [CrossRef]

5. Steffen, W.; Richardson, K.; Rockström, J.; Cornell, S.E.; Fetzer, I.; Bennett, E.M.; Sörlin, S. Planetary boundaries: Guiding human development on a changing planet. Science 2015, 347, 1259855. [CrossRef] 
6. UNEP Food Systems and Natural Resources. A Report of the Working Group on Food Systems of the International Resource Panel. Westhoek, H, Ingram J., Van Berkum, S., Özay, L., and Hajer M. 2016. Available online: https: / www.resourcepanel.org/ reports / food-systems-and-natural-resources (accessed on 10 March 2021).

7. Notarnicola, B.; Tassielli, G.; Renzulli, P.A.; Castellani, V.; Sala, S. Environmental impacts of food consumption in Europe. J. Clean Prod. 2017, 140, 753-765. [CrossRef]

8. IPCC. Special Report on Climate Change, Desertification, Land Degradation, Sustainable Land Management, Food Security, and Greenhouse Gas Fluxes in Terrestrial Ecosystems; Summary for Policy-Makers. 2019. Available online: https://www.ipcc.ch/ site/assets/uploads/2019/08/4.-SPM_Approved_Microsite_FINAL.pdf (accessed on 10 March 2021).

9. HLPE. Nutrition and Food Systems; A report by the High Level Panel of Experts on Food Security and Nutrition of the Committee on World Food Security; FAO: Rome, Italy, 2017.

10. Swinburn, B.A.; Kraak, V.I.; Allender, S.; Atkins, V.J.; Baker, P.I.; Bogard, J.R.; Brinsden, H.; Calvillo, A.; De Schutter, O.; Devarajan, R.; et al. The global syndemic of obesity, undernutrition, and climate change: The Lancet Commission report. Lancet 2019, 393, 791-846. [CrossRef]

11. Hendrickson, M.K.; Howard, P.H.; Miller, E.M.; Constance, D.H. The Food System: Concentration and Its Impacts. A Special Report to the Family Farm Action Alliance. 2020. Available online: https://farmactionalliance.org/concentrationreport/ (accessed on 10 December 2020).

12. FAO; IFAD; UNICEF; WFP; WHO. The State of Food Security and Nutrition in the World 2018. Building Climate Resilience for Food Security and Nutrition; Food and Agriculture Organization of the United Nations: Rome, Italy, 2018. Available online: http:/ / www.fao.org/3/I9553EN/i9553en.pdf (accessed on 10 December 2020).

13. IPES-Food. Towards a Common Food Policy for the EU. The Policy Reform and Realignment That Is Required to Build Sustainable Food Systems in Europe; International Panel of Experts on Sustainable Food Systems: Brussels, Belgium, 2019.

14. Science Advice for Policy by European Academies (SAPEA). A Sustainable Food System for the European Union; SAPEA: Berlin, Germany, 2020.

15. HLPE. Impacts of COVID-19 on Food Security and Nutrition: Developing Effective Policy Responses to Address the Hunger and Malnutrition Pandemic; HLPE Issues Paper; FAO: Rome, Italy, 2020.

16. Anderson, M.D. Pandemic shows deep vulnerabilities. Agric. Hum. Values 2020, 37, 559-560. [CrossRef]

17. Watts, D.C.; Ilbery, B.; Maye, D. Making reconnections in agro-food geography: Alternative systems of food provision. Prog. Hum. Geogr. 2005, 29, 22-40. [CrossRef]

18. Kneafsey, M.; Cox, R.; Holloway, L.; Dowler, E.; Venn, L.; Tuomainen, H. Reconnecting Consumers, Producers, and Food. Exploring Alternatives; Berg: New York, NY, USA, 2008.

19. Wright, W.; Middendorf, G. The Fight over Food: Producers, Consumers, and Activists Challenge the Global Food System; The Pennsylvania State University: University Park, PA, USA, 2008.

20. Maye, D.; Kirwan, J. Alternative Food Networks; Sociology of Agriculture and Food Entry for SOCIOPEDIA.ISA®University of Gloucestershire: Cheltenham, UK, 2010.

21. Goodman, D.; DuPuis, E.M.; Goodman, M. Alternative Food Networks: Knowledge, Practice, and Politics; Routledge: London, UK, 2012.

22. Renting, H.; Schermer, M.; Rossi, A. Building Food Democracy: Exploring Civic Food Networks and Newly Emerging Forms of Food Citizenship. Int. J. Soc. Agric. Food 2012, 19, 289-307.

23. Holloway, L.; Kneafsey, M.; Venn, L.; Cox, R.; Dowler, E.; Tuomainen, H. Possible Food Economies: A Methodological Framework for Exploring Food Production-Consumption Relationships. Sociol. Rural. 2007, 47, 1-19. [CrossRef]

24. Guthman, J. Neoliberalism and the making of food politics in California. Geoforum 2008, 39, 1171-1183. [CrossRef]

25. Johnston, J. The citizen-consumer hybrid: Ideological tensions and the case of Whole Foods Market. Theory Soc. 2008, 37, 229-270. [CrossRef]

26. Harris, E. Neoliberal subjectivities or a politics of the possible? Reading for difference in alternative food networks. Area 2009, 41, 55-63. [CrossRef]

27. Follett, J.R. Choosing a food future: Differentiating among alternative food options. J. Agric. Environ. Ethics 2009, $22,31-51$. [CrossRef]

28. Jones, O.; Kirwan, J.; Morris, C.; Buller, H.; Dunn, R.; Hopkins, A.; Whittington, F.; Wood, J. On the Alternativeness of Alternative Food Networks: Sustainability and the Co-production of Social and Ecological Wealth. In Interrogating Alterity: Alternative Economic and Political Spaces; Ashgate: Oxford, UK, 2010; pp. 95-109.

29. Maye, D. Moving alternative food networks beyond the niche. Int. J. Soc. Agric. Food 2013, 20, 383-389.

30. Constance, D.H.; Friedland, W.H.; Renard, M.-C.; Rivera-Ferre, M.G. The Discourse on Alternative Agrifood Movements. In Alternative Agrifood Movements: Patterns of Convergence and Divergence; Constance, D.H., Renard, M.-C., Rivera-Ferre, M.G., Eds.; Emerald: Binkley, UK, 2014; pp. 3-46.

31. Rossi, A. Beyond Food Provisioning: The Transformative Potential of Grassroots Innovation around Food. Agriculture 2017, 7, 6. [CrossRef]

32. De Schutter, O. The Political Economy of Food Systems Reform. Eur. Rev. Agric. Econ. 2017, 44, 705-731. [CrossRef]

33. Corsi, A.; Barbera, F.; Dansero, E.; Peano, C. (Eds.) Alternative Food Networks. An. Interdisciplinary Assessment; Palgrave Macmillan: Cham, Switzerland, 2018. 
34. Sage, C.; Kropp, C.; Antoni- Komar, I. Grassroots initiatives in food system transformation. The role of food movements in the second 'Great Transformation'. In Food System Transformations. Social Movements, Local Economies, Collaborative Networks; Kropp, C., Antoni-Komar, I., Sage, C., Eds.; Routledge: New York, NY, USA, 2021.

35. Laville, J.-L. The SE: An International Movement. RCCS Annu. Rev. 2010, 2, 1-41.

36. Miller, E. SE: Key Concepts and Issues. In SE I: Building Alternatives for People and Planet; Kawano, E., Masterson, T., Teller-Ellsberg, J., Eds.; Center for Popular Economics: Amherst, MA, USA, 2010; pp. 25-41.

37. Dacheux, E.; Goujon, D. The SE: An alternative development strategy? Int. Soc. Sci. J. 2011, 62, 205-215. [CrossRef]

38. Utting, P. Introduction: The Challenge of Scaling up Social and SE. In Social and SE: Beyond the Fringe; Utting, P., Ed.; Zed Books: London, UK, 2015.

39. RIPESS. Global Vision for a Social SE: Convergences and Differences in Concepts, Definitions and Frameworks. 2015. Available online: http:/ /www.ripess.org/wp-content/uploads/2017/08/RIPESS_Vision-Global_EN.pdf (accessed on 20 June 2020).

40. Laville, J.-L.; Young, D.; Eynaud, P. Civil. Society, the Third Sector and Social Enterprise Governance and Democracy; Routledge: New York, NY, USA, 2015.

41. Marsden, T.; Franklin, A. Replacing neoliberalism: Theoretical implications of the rise of local food movements. Local Environ. 2013, 18, 636-641. [CrossRef]

42. Levkoe, C. Towards a transformative food politics. Local Environ. 2011, 16, 687-705. [CrossRef]

43. Busa, J.H.; Garder, R. Champions of the movement or fair-weather heroes? Individualization and the (a)politics of local food. Antipode 2015, 47, 323-341. [CrossRef]

44. Gaitán-Cremaschi, D.; Klerkx, L.; Duncan, J.; Trienekens, J.H.; Huenchuleo, C.; Dogliotti, S.; Contesse, M.E.; Rossing, W.A.H. Characterizing diversity of food systems in view of sustainability transitions. A review. Agron. Sustain. Dev. 2019, 39, 1-22. [CrossRef]

45. Moragues-Faus, A. Emancipatory or neoliberal food politics? Exploring the "politics of collectivity" of buying groups in the search for egalitarian food democracies. Antipode 2017, 49, 455-476. [CrossRef]

46. Morgan, K. Feeding the City: The Challenge of Urban Food Planning. Int. Plan. Stud. 2009, 14, 341-348. [CrossRef]

47. Morgan, K. The Rise of Urban Food Planning. Int. Plan. Stud. 2013, 18, 1-4. [CrossRef]

48. Harper, A.; Shattuck, A.; Holt-Giménez, E.; Alkon, A.; Lambrick, F. Food Policy Councils: Lessons Learned; Institute for Food and Development Policy: Oakland, CA, USA, 2009. Available online: http://www.farmlandinfo.org/sites/default/files/Food_ Policy_Councils_1.pdf (accessed on 15 July 2020).

49. FAO. Food, Agriculture and Cities. The Challenges of Food and Nutrition Security, Agriculture and Ecosystem Management in an Urbanizing World; FAO: Rome, Italy, 2011. Available online: http:/ / www.fao.org/3/a-au725e.pdf (accessed on 20 December 2020).

50. Sonnino, R.; Spayde, J. The “New Frontier"? Urban strategies for food security and sustainability. In Sustainable Food Systems: Building a New Paradigm; Marsden, T.K., Morley, A.S., Eds.; Routledge-Earthscan Food and Agriculture: London, UK, 2014; pp. 186-205.

51. Moragues-Faus, A.; Morgan, K. Reframing the foodscape: The emergent world of urban. Food Policy. Environ. Plan. A 2015, 47, 1558-1573. [CrossRef]

52. Blay-Palmer, A.; Renting, H.; Dubbeling, M. City-Region Food Systems. A Literature Review. 2015. Available online: http: / / www.ruaf.org/sites/default/files/CityRegionFoodSystemsliteraturereview.pdf (accessed on 10 July 2020).

53. FAO. FAO Framework for the Urban. Food Agenda; FAO: Rome, Italy, 2019. [CrossRef]

54. Biolghini, D. Il popolo dell'Economia Solidale. Alla Ricerca di un'Altra Economia; EMI: Bologna, Italy, 2007.

55. Tavolo per la Rete Italiana di Economia Solidale (Ed.) Un'Economia Nuova, dai Gas. alla Zeta; Altreconomia: Milano, Italy, 2013.

56. Bertell, L.; Deriu, M.; De Vita, A.; Gosetti, G. Davide e Golia. La Primavera delle Economie Diverse GAS, DES, RES; Jaca Book: Milano, Italy, 2013.

57. Coscarello, M. Le Reti di Economia Solidale. Comunità di Pratiche per una Trasformazione Sociale; Centro Editoriale e Librario, Università della Calabria: Cosenza, Italy, 2014.

58. Biolghini, D.; Coscarello, M.; Guarascio, C.; Rossi, A.; Troisi, R.; Vulcano, G. Oltre il consumo critico: Progetti di comunità per l'economia solidale. In Territori e Comunità. Le Sfide dell'Autogoverno Comunitario; Gisotti, M.R., Rossi, M., Eds.; Ricerche e Studi Territorialisti; SdT edizioni: Firenze, Italy, 2020; Volume 5, pp. 287-297.

59. Berti, G.; Rossi, A. La capacità di governance democratica del cibo a livello locale: Le esperienze di Livorno e Pisa. In Lo Spazio delle Politiche Locali del Cibo: Temi, Esperienze e Prospettive; Dansero, E., Marino, D., Mazzocchi, G., Nicolarea, Y., Eds.; Celid: Torino, Italy, 2019; pp. 93-105.

60. Forno, F.; Maurano, S.; Vittori, F. Costruire processi partecipativi attorno al cibo: Le esperienze di Bergamo e Trento. In Lo Spazio delle Politiche Locali del Cibo: Temi, Esperienze e Prospettive; Dansero, E., Marino, D., Mazzocchi, G., Nicolarea, Y., Eds.; Celid: Torino, Italy, 2019.

61. Marino, D.; Mazzocchi, G. Roma, una policy senza politica: Il processo partecipativo per una politica del cibo a scala metropolitana. In Lo Spazio delle Politiche Locali del Cibo: Temi, Esperienze e Prospettive; Dansero, E., Marino, D., Mazzocchi, G., Nicolarea, Y., Eds.; Celid: Torino, Italy, 2019.

62. Winson, A. The Industrial Diet: The Degradation of Food and the Struggle for Healthy Eating; NYU Press: New York, NY, USA, 2013.

63. Otero, G. The Neoliberal Diet: Healthy Profits, Unhealthy People; University of Texas Press: Austin, TX, USA, 2018. 
64. Vulcano, G.; Ciccarese, L. Spreco Alimentare: Un Approccio Sistemico per la Prevenzione e la Riduzione Strutturali; ISPRAIstituto Superiore per la Protezione e la Ricerca Ambientale, Rapporti 279/2018; ISPRA: Rome, Italy, 2018. Available online: https://www.isprambiente.gov.it/it/pubblicazioni/rapporti/spreco-alimentare-un-approccio-sistemico-per-la-prevenzionee-la-riduzione-strutturali-1 (accessed on 10 October 2019).

65. HLPE. Food Losses and Waste in the Context of Sustainable Food Systems; A report by the High Level Panel of Experts on Food Security and Nutrition of the Committee on World Food Security; FAO: Rome, Italy, 2014. Available online: http:/ /www.fao.org/ 3/a-i3901e.pdf (accessed on 10 December 2020).

66. Patel, R. I Padroni del Cibo; Feltrinelli: Milano, Italy, 2008.

67. McMichael, P. A food regime analysis of the 'world food crisis'. Agric. Hum. Values 2009, 26, 281. [CrossRef]

68. Clapp, J.; Fuchs, D.A. Corporate Power in Global Agrifood Governance; MIT Press: Cambridge, MA, USA, 2009.

69. Lang, T.; Heasman, M. Food Wars: The Global Battle for Mouths, Minds and Markets, 2nd ed.; Routledge: New York, NY, USA, 2015.

70. Howard, P. Concentration and Power in the Food System: Who Controls What We Eat? Bloomsbury Academic: New York, NY, USA, 2016.

71. Van der Ploeg, J.D.; van Dijk, G. (Eds.) Beyond Modernization. The Impact of Endogenous Rural Development; Van Gorcum: Assen, The Netherlands, 1995.

72. IPES-Food. Too Big to Feed: Exploring the Impacts of Mega-Mergers, Consolidation and Concentration in the Agro-Food Sector; International Panel of Experts on Sustainable Food Systems: Brussels, Belgium, 2017. Available online: www.ipes-food.org (accessed on 20 January 2019).

73. Lyson, T.A. Civic Agriculture: Reconnecting Farm, Food, and Community; University Press of New England: Lebanon, NH, USA, 2004.

74. van der Ploeg, J.D. The New Peasantries: Struggles for Autonomy and Sustainability in an Era of Empire and Globalization; Routledge: London, UK, 2008.

75. Marsden, T.K.; Morley, A.S. (Eds.) Sustainable Food Systems: Building a New Paradigm; Routledge: London, UK, 2014.

76. Czyżewski, B.; Czyżewski, A.; Kryszak, Ł. The market treadmill against sustainable income of European Farmers: How the CAP has struggled with Cochrane's curse. Sustainability 2019, 11, 791. [CrossRef]

77. Jaffe, J.; Gertler, M. Victual vicissitudes: Consumer deskilling and the (gendered) transformation of food systems. Agric. Hum. Values 2006, 23, 143-162. [CrossRef]

78. Dawson, J. Retailer activity in shaping food choice. Food Qual. Prefer. 2013, 1, 339-347. [CrossRef]

79. Schneider, M.; McMichael, P. Deepening, and Repairing, the Metabolic Rift. J. Peasant Stud. 2010, 37, 461-484. [CrossRef] [PubMed]

80. De Schutter, O. Final Report: The Transformative Potential of the Right to Food; Report of the Special Rapporteur on the Right to Food, Olivier De Schutter; United Nations General Assembly Human Rights Council: Geneva, Switzerland, 2014.

81. UNCTAD. UNCTAD Annual Report 2013; United Nations: Geneva, Switzerland, 2013. Available online: https://unctad.org/en/ PublicationsLibrary /dom2014d1_en.pdf (accessed on 20 February 2021).

82. FAO; IFAD; WFP. The State of Food Insecurity in the World 2015. Meeting the 2015 International Hunger Targets: Taking Stock of Uneven Progress; FAO: Rome, Italy, 2015.

83. IPES-Food. From Uniformity to Diversity: A Paradigm Shift from Industrial Agriculture to Diversified Agroecological Systems; International Panel of Experts on Sustainable Food Systems: Brussels, Belgium, 2016.

84. Lang, T.; Barling, D. Food security and food sustainability: Reformulating the debate. Geogr. J. 2012, 178, 313-326. [CrossRef]

85. IPES-Food. The New Science of Sustainable Food Systems. Overcoming Barriers to Food System Reform; International Panel of Experts on Sustainable Food Systems: Brussels, Belgium, 2015.

86. European Commission. Recipe for Change: An Agenda for a Climate-Smart and Sustainable Food System for a Healthy Europe; Report of the EC FOOD 2030 Independent Expert Group; Publications Office of the European Union: Luxembourg, 2018.

87. European Commission. Resilience and Transformation; Report of the 5th SCAR Foresight Exercise Expert Group-Natural Resources and Food Systems: Transitions towards a 'Safe and Just' Operating Space; Publications Office of the European Union: Luxembourg, 2020.

88. Wiskerke, J.S. On places lost and places regained: Reflections on the alternative food geography and sustainable regional development. Int. Plan. Stud. 2009, 14, 369-387. [CrossRef]

89. Marsden, T. Third Natures? Reconstituting Space through Place-making Strategies for Sustainability. Int. J. Sociol. Agric. Food 2012, 19, 257-274.

90. Candel, J.L. What's on the menu? A global assessment of MUFPP signatory cities' food strategies. Agroecol. Sustain. Food Syst. 2020, 44, 919-946. [CrossRef]

91. Deakin, D.; Diamantini, D.; Borrelli, N. The Governance of City Food Systems; Fondazione Feltrinelli: Milano, Italy, 2015.

92. Gupta, C.; Campbell, D.; Munden-Dixon, K.; Sowerwine, J.; Capps, S.; Feenstra, G.; van Soelen Kim, J. Food policy councils and local governments: Creating effective collaboration for food systems change. J. Agric. Food Syst. Community Dev. 2018, 8, 11-28. [CrossRef]

93. Coulson, H.; Sonnino, R. Re-scaling the politics of food: Place-based urban food governance in the UK. Geoforum 2019, 98, 170-179. [CrossRef]

94. Blay-Palmer, A.; Sonnino, R.; Custot, J. A food politics of the possible? Growing sustainable food systems through networks of knowledge. Agric. Hum. Values 2016, 33, 27-43. [CrossRef] 
95. Mansfield, B.; Mendes, W. Municipal Food Strategies and Integrated Approaches to Urban Agriculture: Exploring Three Cases from the Global North. Int. Plan. Stud. 2013, 18, 37-60. [CrossRef]

96. Candel, J.L.; Pereira, L. Towards integrated food policy: Main challenges and steps ahead. Environ. Sci. Policy 2017, 73, 89-92. [CrossRef]

97. Hebinck, A.; Page, D. Processes of Participation in the Development of Urban Food Strategies: A Comparative Assessment of Exeter and Eindhoven. Sustainability 2017, 9, 931. [CrossRef]

98. Cini, L.; Felicetti, A. Participatory deliberative democracy: Toward a new standard for assessing democracy? Some insights into the Italian case. Contemp. Ital. Politics 2018, 10, 151-169. [CrossRef]

99. Sieveking, A. Food Policy Councils as Loci for Practising Food Democracy? Insights from the Case of Oldenburg, Germany. Politics Gov. 2019, 7, 48-58. [CrossRef]

100. Renting, H.; Marsden, T.K.; Banks, J. Understanding alternative food networks: Exploring the role of short food supply chains in rural development. Environ. Plan. 2003, 35, 393-411. [CrossRef]

101. Tregear, A. Progressing knowledge in alternative and local food networks: Critical reflections and a research agenda. J. Rural Stud. 2011, 27, 419-430. [CrossRef]

102. Kneafsey, M.; Venn, L.; Schmutz, U.; Balázs, B.; Trenchard, L.; Eyden-Wood, T.; Bos, E.; Sutton, G.; Blackett, M. Short Food Supply Chains and Local Food Systems in the EU. A State of Play of Their Socio-Economic Characteristics; JRC Scientific and Policy Reports; Publications Office of the European Union: Bruxelles, Belgium, 2013.

103. Plumecocq, G.; Debril, T.; Duru, M.; Magrini, M.B.; Sarthou, J.P.; Therond, O. The plurality of values in sustainable agriculture models: Diverse lock-in and coevolution patterns. Ecol. Soc. 2018, 23, 21. [CrossRef]

104. Holt Giménez, E.; Shattuck, A. Food crises, food regimes and food movements: Rumblings of reform or tides of transformation? J. Peasant Stud. 2011, 38, 109-144. [CrossRef]

105. Vivero-Pol, J.L. Transition towards a food commons regime: Re-commoning food to crowd-feed the world. In Perspectives on Commoning: Autonomist Principles and Practice; Ruivenkamp, G., Hilton, A., Eds.; Zed Books: London, UK, 2015 ; pp. 325-379.

106. Rundgren, G. From Commodity to Commons. J. Agric. Environ. Ethics 2016, 29, 103-121. [CrossRef]

107. Marsden, T.; Banks, J.; Bristow, G. Food supply chain approaches: Exploring their role in rural development. Sociol. Rur. 2000, 40, 424-438. [CrossRef]

108. Hinrichs, C.C. Transitions to sustainability: A change in thinking about food systems change? Agric. Hum. Values 2014, 31, 143-155. [CrossRef]

109. Van der Ploeg, J.D.; Marsden, T. (Eds.) Unfolding Webs: The Dynamics of Regional Rural Development (European Perspectives on Rural Development); Royal van Gorcum: Assen, NL, USA, 2008.

110. Lamine, C.; Renting, H.; Rossi, A.; Wiskerke, H.; Brunori, G. Agri-food systems and territorial development: Innovations, new dynamics and changing governance mechanisms. In The Farming Systems Approaches into the 21st Century: The New Dynamic; Springer Science+Business Media Dordrecht: Dordrecht, The Netherlands, 2012; pp. 227-255.

111. Roep, D.; Wiskerke, J. On Governance, Embedding and Marketing: Reflections on the Construction of Alternative Sustainable Food Networks. J. Agric. Environ. Ethics 2012, 25, 205-221. [CrossRef] [PubMed]

112. Hassanein, N. Practising food democracy: A pragmatic politics of transformation. J. Rural Stud. 2003, 19, 77-86. [CrossRef]

113. Wilkins, J.L. Eating right here: Moving from consumer to food citizen. Agric. Hum. Values 2005, 22, 269-273. [CrossRef]

114. Lockie, S. Responsibility and agency within alternative food networks: Assembling the "citizen consumer". Agric. Hum. Values 2009, 26, 193-201. [CrossRef]

115. Alkon, A.H.; Agyeman, J. Cultivating Food Justice: Race, Class., and Sustainability; The MIT Press: Cambridge, MA, USA, 2011.

116. Patel, R. Food sovereignty. J. Peasant Stud. 2009, 36, 663-706. [CrossRef]

117. Wittman, H.; Desmarais, A.A.; Wiebe, N. (Eds.) Food Sovereignty: Reconnecting Food, Nature and Community; Food First: Oakland, CA, USA, 2010.

118. Hospes, O. Food sovereignty: The debate, the deadlock, and a suggested detour. Agric. Hum. Values 2014, 31, 119-130. [CrossRef]

119. Wilson, M.L. (Ed.) Postcolonialism, Indigeneity and Struggles for Food Sovereignty. Alternative Food Networks in the Subaltern World; Routledge, Taylor \& Francis Group: London, UK, 2017.

120. Gómez-Benito, C.; Lozano, C. Constructing Food Citizenship: Theoretical Premises and Social Practices. Ital. Sociol. Rev. 2014, 4, 135-156. Available online: https://www.researchgate.net/publication/287323540_Constructing_Food_Citizenship_Theoretical_ Premises_and_Social_Practices (accessed on 20 October 2020).

121. Campisi, J. Food citizenship. In Encyclopedia of Food and Agri-Cultural Ethics; Thompson, P.B., Kaplan, D.M., Eds.; Springer: Dordrecht, The Netherlands, 2016; pp. 1-5.

122. Goldberg, R.A. Food Citizenship. Food System Advocates in an Era of Distrust; Oxford University Press: Oxford, UK, 2018.

123. United Nations Task Force on Social and SE (UNTFSSE). Social and SE and the Challenge of Sustainable Development. A Position Paper by the United Nations Inter-Agency Task Force on Social and SE. 2014. Available online: http://unsse.org/wp-content/ uploads/2014/08/Position-Paper_TFSSE_Eng1.pdf (accessed on 10 July 2020).

124. Loorbach, D.; Wittmayer, J.; Avelino, F.; von Wirth, T.; Frantzeskaki, N. Transformative innovation and translocal diffusion. Environ. Innov. Soc. Transit. 2020, 35, 251-260. [CrossRef] 
125. Moragues-Faus, A. Urban Food Policy Alliances as Paths to Food Sovereignty? Insights from Sustainable Food Cities in the UK. In Public Policies For. Food Sovereignty: Social Movements And The State; Desmarais, A.A., Claeys, P., Trauger, A., Eds.; Routledge: London, UK, 2017.

126. Saroldi, A. Gruppi di Acquisto Solidali. Esperienze; EMI: Verona, Italy, 2001.

127. Carrera, L. I gruppi di acquisto solidale. Una proposta solida nella società liquida. Partecip. Confl. 2009, 3, 95-122. [CrossRef]

128. Tavolo per la Rete italiana di Economia Solidale. In Il Capitale delle Relazioni; Altraeconomia: Milano, Italy, 2010.

129. Rossi, A.; Brunori, G. Le pratiche di consumo alimentare come fattori di cambiamento. Il caso dei Gruppi di Acquisto Solidale. Agriregionieuropa 2011, 27, 86.

130. Brunori, G.; Rossi, A.; Malandrin, V. Co-producing Transition: Innovation Processes in Farms Adhering to Solidarity-based Purchase Groups (GAS) in Tuscany, Italy. Int. J. Sociol. Agric. Food 2011, 18, 28-53.

131. Brunori, G.; Rossi, A.; Guidi, F. On the new social relations around and beyond food. Analysing consumers' role and action in Gruppi di Acquisto Solidale (Solidarity Purchasing Groups). Sociol. Rural. 2012, 52, 1-30. [CrossRef]

132. Forno, F.; Grasseni, C.; Signori, S. Oltre la spesa. I Gruppi di Acquisto Solidale come laboratori di cittadinanza e palestre di democrazia. Sociol. Lav. 2013, 132, 127-142. [CrossRef]

133. Fonte, M. Food consumption as social practice: Solidarity Purchasing Groups in Rome, Italy. J. Rur. Stud. 2013, 32, 230-239. [CrossRef]

134. Cembalo, L.; Migliore, G.; Schifani, G. Sustainability and New Models of Consumption: The Solidarity Purchasing Groups in Sicily. J. Agric. Environ. Ethics 2013, 26, 281-303. [CrossRef]

135. Brunori, G.; Rossi, A.; Cerruti, R.; Guidi, F. Nicchie produttive e innovazione di sistema: Un'analisi secondo l'approccio delle transizioni tecnologiche attraverso il caso dei farmers' markets in Toscana. Econ. Agro-Aliment. 2009, 3, 143-170.

136. Genova, A.; Piccoli, A. L'agricoltura supportata dalla comunità in Italia: Timide pratiche di consumerismo politico. Cult. Sostenibilità 2019, 24, 46-56.

137. Gagliotta, C. Le Nuove Tendenze del Consumo Alimentare: Consumo Sostenibile e Consumo Critico. Alternative Food Networks: Il Case Study del Distretto di Economia Solidale OltreConfin e il Progetto Csa Veneto; Università Ca' Foscari: Venezia, Italy, 2019.

138. Auriemma, M.; Cacciari, P.; Cervesato, M.; Cristiano, S.; Maffeo, D.; Malgaretto, P.; Nordio, F.; Toniolo, A. CSA Veneto, Comunità che supporta l'agricoltura. In cammino verso l'autonomia alimentare. In Territori e Comunità. Le Sfide dell'Autogoverno Comunitario; Gisotti, M.R., Rossi, M., Eds.; Ricerche e Studi Territorialisti, SdT edizioni: Firenze, Italy, 2020; Volume 5, pp. 251-266.

139. Chiffoleau, Y.; Millet-Amrani, S.; Rossi, A.; Rivera-Ferre, M.G.; Merino, P.L. The participatory construction of new economic models in short food supply chains. J. Rural Stud. 2019, 68, 182-190. [CrossRef]

140. Cacciari, P. 101 Piccole Rivoluzioni: Storie di Economia Solidale e Buone Pratiche dal Basso; Altreconomia: Milano, Italy, 2016.

141. Mostaccio, F. L'economia solidale come autodifesa della società. L'esperienza di Rosarno. Sociol. Lav. 2016, 142, 164-176. [CrossRef]

142. Biolghini, D.; Bonaiuti, M.; Burlando, R.; Cacciari, P.; Castagnola, A.; Deriu, M.; Di Paolo, P.; Di Vece, L.; Domeneghini, D.; Mance, E.A.; et al. I Dialoghi dell'Economia Solidale. Scenari e Concetti per una Transizione Possibile, 1st ed.; Asterios: Trieste, Italy, 2016.

143. Berger, P.L.; Luckman, T. The Social Construction of Reality; Penguin Books: New York, NY, USA, 1966.

144. Crotty, M. The Foundations of Social Research: Meaning and Perspective in the Research Process; SAGE: Thousand Oaks, CA, USA, 1998.

145. Crozier, G.; Denzin, N.; Lincoln, Y. Handbook of Qualitative Research, 2nd ed.; Sage: Thousand Oaks, CA, USA, 2000.

146. Holland, J.; Thomson, R.; Henderson, S. Qualitative Longitudinal Research: A Discussion Paper. In Families E Social Capital ESRC Research Group Working Paper No. 21; London South Bank University: London, UK, 2006.

147. Roper, J.M.; Shapira, J. Ethnography in Nursing Research; Sage: Thousand Oaks, CA, USA, 2000; 160p.

148. Angrosino, M.V. Doing Ethnographic and Observational Research; SAGE Publications Ltd.: Thousand Oaks, CA, USA, 2007.

149. Reason, P.; Bradbury, H. (Eds.) Handbook of Action Research: Participative Inquiry and Practice; Sage: Thousand Oaks, CA, USA, 2001.

150. Kindon, S.; Pain, R.; Kesby, M. Participatory Action Research Approaches and Methods: Connecting People, Participation and Place; Routledge: London, UK, 2007.

151. Chevalier, J.M.; Buckles, D.J. Handbook For Participatory Action Research, Planning and Evaluation. SAS2 Dialogue. 2012. Available online: www.participatoryactionresearch.net (accessed on 20 January 2021).

152. Merriam, S. Qualitative Research: A Guide to Design and Implementation, 2nd ed.; The Jossey-Bass Higher and Adult Education Series; Jossey-Bass: San Francisco, CA, USA, 2009.

153. Murray, R.; Caulier, G.; Mulgan, G. The Open Book of Social Innovation; The Young Foundation \& NESTA: London, UK, 2010. Available online: https:/ /youngfoundation.org/wp-content/uploads/2012/10/The-Open-Book-of-Social-Innovationg.pdf (accessed on 15 June 2020).

154. Bureau of European Policy Advisors (BEPA). Empowering People, Driving Change: Social Innovation in the European Union; EUR-OP: Luxembourg, 2010.

155. Moulaert, F.; MacCallum, D.; Hillier, J. Social innovation: Intuition, precept, concept, theory and practice. In The International Handbook on Social Innovation. Collective Action, Social Learning and Transdisciplinary Research; Moulaert, F., MacCallum, D., Mehmood, A., Hamdouch, A., Eds.; Edward Elgar Publishing Limited: Cheltenham, UK, 2013.

156. Moulaert, F.; MacCallum, D.; Mehmood, A.; Hamdouch, A. General introduction: The return of social innovation as a scientific concept and a social practice. In The International Handbook on Social Innovation. Collective Action, Social Learning and Transdisciplinary 
Research; Moulaert, F., MacCallum, D., Mehmood, A., Hamdouch, A., Eds.; Edward Elgar Publishing Limited: Cheltenham, UK, 2013; pp. 1-8.

157. Pol, E.; Ville, S. Social innovation: Buzz word or enduring term? J. Socio-Econ. 2009, 38, 878-885. [CrossRef]

158. Klein, J.L.; Fontan, J.M.; Harrisson, D.; Lévesque, B. The Québec Model: A social innovation system founded on cooperation and consensus building. In The International Handbook on Social Innovation. Collective Action, Social Learning and Transdisciplinary Research; Moulaert, F., MacCullam, D., Mehmood, A., Hamdouch, A., Eds.; Elgar: Cheltenham, UK, 2013; pp. $371-383$.

159. Phills, J.A., Jr.; Deiglmeier, K.; Miller, D.T. Rediscovering Social Innovation. Stanf. Soc. Innov. Rev. 2008, 6, 33-43.

160. Marg, S.; Geiges, L.; Butzlaff, F.; Walter, F. (Eds.) Die Neue Macht der Bürger. Was Motiviert Protestbewegungen? BP-Gesellschaftsstudie; Bundeszentrale für Politische Bildung: Bonn, Germany, 2013.

161. Howaldt, J.; Domanski, D.; Kaletka, C. Social Innovation: Towards a New Innovation Paradigm RAM, REV. ADM. MACKENZIE (Mackenzie Management Review), Special ed.; Universidade Presbiteriana Mackenzie: Sao Paulo, Brazil, 2016; p. 17. Available online: https: / / www.redalyc.org/pdf/1954/195449449003.pdf (accessed on 20 July 2020).

162. Haxeltine, A.; Avelino, F.; Wittmayer, J.; Kemp, R.; Weaver, P.; Backhaus, J.; O’Riordan, T. Transformative social innovation: A sustainability transitions perspective on social innovation. In Proceedings of the NESTA Social Innovation Research Conference, London, UK, 14-15 November 2013. Available online: http:/ / www.scribd.com/doc/191799102/Transformative-socialinnovations-A-sustainability-transition-perspective-on-social-innovation (accessed on 30 November 2020).

163. Haxeltine, A.; Avelino, F.; Pel, B.; Kemp, R.; Dumitru, A.; Longhurst, N.; Chilvers, J.; Søgaard Jørgensen, M.; Wittmayer, J.; Seyfang, G.; et al. TRANSIT WP3 Deliverable D3.3-A Second Prototype of TSI Theory. 2016. Available online: http://www. transitsocialinnovation.eu/resource-hub/transit-wp3-deliverable-d33-a-second-prototype-of-tsi-theory-deliverable-no-d33 (accessed on 30 November 2020).

164. Micheletti, M. Political Virtue and Shopping. Individuals, Consumerism, and Collective Action; Palgrave Macmillan: New York, NY, USA, 2003.

165. Holzer, B. Political consumerism between individual choice and collective action: Social movements, role mobilization and signalling. Int. J. Consum. Stud. 2006, 30, 405-415. [CrossRef]

166. Desmarais, A.A. The Via Campesina: Consolidating an International Peasant and Farm Movement. J. Peasant Stud. 2002, 29, 91-124. [CrossRef]

167. Nyéléni. Nyéléni 2007-Forum for Food Sovereignity; Synthesis Report. 2007. Available online: https:/ / nyeleni.org/spip.php? article334 (accessed on 20 March 2021).

168. Sage, C. The transition movement and food sovereignty: From local resilience to global engagement in food system transformation. J. Consum. Cult. 2014, 14, 254-275. [CrossRef]

169. McMichael, P. Historicizing Food Sovereignty. J. Peasant Stud. 2014, 41, 933-957. [CrossRef]

170. Vivero-Pol, J.L. Food as Commons or Commodity? Exploring the Links between Normative Valuations and Agency in Food Transition. Sustainability 2017, 9, 442. [CrossRef]

171. Ferrando, T.; Vivero-Pol, J.L. Commons and 'commoning': A 'new' old narrative to enrich the food sovereignty and right to food claims. Right Food Nutr. Watch 2017, 10, 50-56.

172. Pettenati, G.; Toldo, A.; Ferrando, T. The food system as a commons. In Routledge Handbook of Food as a Commons; Vivero-Pol, J.L., Ferrando, T., De Schutter, O., Mattei, U., Eds.; Routledge: Abingdon, UK, 2019; pp. 42-56.

173. De Schutter, O.; Mattei, U.; Vivero-Pol, J.L.; Ferrando, T. Food as Commons. Towards a new relationship between the public, the civic and the private. In Routledge Handbook of Food as a Commons, 1st ed.; Vivero-Pol, J.L., Ferrando, T., De Schutter, O., Mattei, U., Eds.; Routledge: Abingdon, UK, 2019; pp. 373-395.

174. Sacchi, G. I Sistemi di Garanzia Partecipativa per i prodotti biologici. Agriregionieuropa 2018, 14.

175. Bouagnimbeck, H. The Global Comparative Study on Interaction between Social Processes and Participatory Guarantee Systems; IFOAM: Bonn, Germany, 2014. Available online: https://www.ifoam.bio/sites/default/files/2020-05/global_study_on_interactions_ between_social_processes_and_participatory_guarantee_systems.pdf (accessed on 25 February 2021).

176. Salvi, S.; Vittori, F. I Sistemi Partecipativi di Garanzia, Working Paper Series 1 - Osservatorio; CORES: Bergamo, Italy, 2017.

177. Mance, E. Circuiti Economici Solidali; Pioda Imaging: Roma, Italy, 2017.

178. Biolghini, D. Terra e Cibo, per costruire una comunità resiliente. In Scienze del Territorio 7; University Press: Firenze, Italy, 2019.

179. ActionAid. La Pandemia Che Affama l'Italia. Covid-19, Povertà Alimentare e Diritto al Cibo. 2020. Available online: https: / / www.actionaid.it/informati/pubblicazioni/la-pandemia-che-affama-italia (accessed on 20 January 2021).

180. Coscarello, M.; Sivini, S. Le risposte dell'economia solidale all'emergenza Covid-19. In Studiare la Pandemia. Disuguaglianze e Resilienza ai Tempi del Covid-19; Cersosimo, D., Cimatti, F., Raniolo, F., Eds.; Donzelli Editore: Roma, Italy, 2020.

181. Rossi, A.; Biolghini, D. I percorsi attorno all'agricoltura nella cornice dell'Economia Solidale. Agriregionieuropa. 2016. Available online: https://agriregionieuropa.univpm.it/it/content/article/31/45/i-percorsi-attorno-allagricoltura-nella-cornicedelleconomia-solidale (accessed on 20 January 2021).

182. Ferrando, T.; Claeys, P.; Diesner, D.; Vivero-Pol, J.L.; Woods, D. Commons and Commoning for a Just Agroecological Transition: How to Decolonise and Decommodify our Food Systems. In Resourcing an Agroecological Urbanism: Political, Transformational and Territorial Dimensions; Tornaghi, C., Dehaene, M., Eds.; Routledge: London, UK, 2021.

183. Dansero, E.; Marino, D.; Mazzocchi, G.; Nicolarea, Y. (Eds.) Lo Spazio delle Politiche Locali del Cibo: Temi, Esperienze e Prospettive, Collana Atlante del Cibo; CELID: Torino, Italy, 2019; pp. 93-105. 
184. Andrée, P.; Clark, J.K.; Levkoe, C.Z.; Lowitt, K.; Johnston, C. The governance engagement continuum. In Civil. Society and Social Movements in Food System Governance; Andrée, P., Clark, J.K., Levkoe, C.Z., Lowitt, K., Eds.; Routledge: London, UK, 2019; pp. 33-42.

185. Bornemann, B.; Weiland, S. Empowering People-Democratising the Food System? Exploring the Democratic Potential of Food-Related Empowerment Forms. Politics Gov. 2019, 7, 105-118. [CrossRef] 